\title{
NADPH oxidases as a source of oxidative stress and molecular target in ischemia/reperfusion injury
}

Citation for published version (APA):

Kleikers, P. W. M., Wingler, K., Hermans, J. J. R., Diebold, I., Altenhofer, S., Radermacher, K. A., Janssen, B., Goerlach, A., \& Schmidt, H. H. H. W. (2012). NADPH oxidases as a source of oxidative stress and molecular target in ischemia/reperfusion injury. Journal of Molecular Medicine, 90(12), 13911406. https://doi.org/10.1007/s00109-012-0963-3

Document status and date:

Published: 01/12/2012

DOI:

10.1007/s00109-012-0963-3

Document Version:

Publisher's PDF, also known as Version of record

Document license:

Taverne

Please check the document version of this publication:

- A submitted manuscript is the version of the article upon submission and before peer-review. There can be important differences between the submitted version and the official published version of record.

People interested in the research are advised to contact the author for the final version of the publication, or visit the DOI to the publisher's website.

- The final author version and the galley proof are versions of the publication after peer review.

- The final published version features the final layout of the paper including the volume, issue and page numbers.

Link to publication

\footnotetext{
General rights rights.

- You may freely distribute the URL identifying the publication in the public portal. please follow below link for the End User Agreement:

www.umlib.nl/taverne-license

Take down policy

If you believe that this document breaches copyright please contact us at:

repository@maastrichtuniversity.nl

providing details and we will investigate your claim.
}

Copyright and moral rights for the publications made accessible in the public portal are retained by the authors and/or other copyright owners and it is a condition of accessing publications that users recognise and abide by the legal requirements associated with these

- Users may download and print one copy of any publication from the public portal for the purpose of private study or research.

- You may not further distribute the material or use it for any profit-making activity or commercial gain

If the publication is distributed under the terms of Article $25 \mathrm{fa}$ of the Dutch Copyright Act, indicated by the "Taverne" license above, 


\title{
NADPH oxidases as a source of oxidative stress and molecular target in ischemia/reperfusion injury
}

\author{
Pamela W. M. Kleikers • K. Wingler • J. J. R. Hermans • \\ I. Diebold • S. Altenhöfer - K. A. Radermacher • \\ B. Janssen • A. Görlach • H. H. H. W. Schmidt
}

Received: 1 March 2012 /Revised: 26 September 2012 /Accepted: 28 September 2012 /Published online: 23 October 2012

(C) Springer-Verlag Berlin Heidelberg 2012

\begin{abstract}
Ischemia/reperfusion injury (IRI) is crucial in the pathology of major cardiovascular diseases, such as stroke and myocardial infarction. Paradoxically, both the lack of oxygen during ischemia and the replenishment of oxygen during reperfusion can cause tissue injury. Clinical outcome is also determined by a third, post-reperfusion phase characterized by tissue remodeling and adaptation. Increased levels of reactive oxygen species (ROS) have been suggested to be key players in all three phases. As a second paradox, ROS seem to play a double-edged role in IRI, with both detrimental and beneficial effects. These Janus-faced effects of ROS may be linked to the different sources of ROS or to the different types of ROS that exist and may also depend on the phase of IRI. With respect to therapeutic implications, an untargeted application of antioxidants may not differentiate between detrimental and beneficial ROS, which might explain why this approach is clinically ineffective in lowering cardiovascular mortality. Under some conditions, antioxidants even appear to be harmful. In this review, we discuss recent breakthroughs regarding a more targeted and promising approach to therapeutically modulate ROS in IRI. We will focus on
\end{abstract}

P. W. M. Kleikers $(\bowtie) \cdot$ K. Wingler · J. J. R. Hermans •

S. Altenhöfer $\cdot$ K. A. Radermacher $\cdot$ B. Janssen $\cdot$

H. H. H. W. Schmidt

Vascular Drug Discovery Group (VDDG), Department of

Pharmacology and Cardiovascular Research Institute Maastricht

(CARIM), Faculty of Health, Medicine and Life Sciences,

Maastricht University,

Universiteitssingel 50,

6229 ER Maastricht, The Netherlands

e-mail: p.kleikers@maastrichtuniversity.nl

I. Diebold · A. Görlach

Experimental and Molecular Pediatric Cardiology, German Heart

Center Munich at the Technical University Munich,

Munich, Germany
NADPH oxidases and their catalytic subunits, NOX, as they represent the only known enzyme family with the sole function to produce ROS. Similar to ROS, NADPH oxidases may play a dual role as different NOX isoforms may mediate detrimental or protective processes. Unraveling the precise sequence of events, i.e., determining which role the individual NOX isoforms play in the various phases of IRI, may provide the crucial molecular and mechanistic understanding to finally effectively target oxidative stress.

Keywords NADPH oxidases $\cdot$ NOX $\cdot$ Ischemia/reperfusion injury · Oxidative stress $\cdot$ ROS

\section{Introduction}

Stroke and myocardial infarction (MI) are two major causes of death and disability in Western countries. Both are caused by organ ischemia followed by varying degrees of reperfusion. Reactive oxygen species (ROS) are thought to be the key players in this ischemia/ reperfusion injury (IRI) $[1,2]$. Consequently, treatment of IRI should be directed to these key players. The untargeted use of antioxidants, however, failed to show any clinical benefits after stroke [3, 4] or MI [5, 6]. Indeed, specifically targeting the pathological source of ROS may provide a better therapeutic approach. Among such potential ROS sources, NADPH oxidases are the only known enzymes with the sole function of producing ROS. In the cardiovascular system, NAPDH oxidases account for a major part of the ROS formed, not only during IRI but also under physiologic conditions [7]. Here, we review the pathophysiology of IRI, focusing on NADPH oxidases as new potential targets for therapeutic interventions. 


\section{Ischemia/reperfusion injury: two paradoxes}

During ischemia or the subsequent reperfusion, damage can occur in cells or tissues, which often is irreversible. This damage is referred to as IRI $[1,8]$. IRI can be divided into three phases.

During the first, ischemic phase, interruption of the blood flow to an organ causes a (temporary) lack of oxygen and nutrients $[1,2,8,9]$. The generation of adenosine triphosphate (ATP) via oxidative phosphorylation is disturbed during ischemia, causing cells to alter their metabolism. The reduced availability of ATP limits the activity of the ATPdependent $\mathrm{Na}^{+} / \mathrm{K}^{+}$pump $[1,2]$, which constraints the outflow of calcium via the $\mathrm{Na}^{+} / \mathrm{Ca}^{2+}$ exchanger [8]. This results in calcium overload, causing structural disorganization as well as apoptotic and necrotic death of cells $[2,8,9]$. In addition, chemokines and adhesion molecules promote a proinflammatory state $[1,2,10]$. Moreover, the altered cellular metabolism leads to an accumulation of precursors of oxidative phosphorylation, and it causes damage to or conformational changes of enzymes such as xanthine oxidase. These latter processes are not directly detrimental to cells, but they become important in the next phase of IRI by increasing ROS generation $[1,8,9]$.

The second phase of IRI constitutes the reestablishment of blood flow and thus the reintroduction of oxygen. Although oxygen is needed for survival, it can also be detrimental because it can be converted to ROS such as hydrogen peroxide $\left(\mathrm{H}_{2} \mathrm{O}_{2}\right)$ and superoxide $\left(\mathrm{O}_{2}{ }^{-}\right)$[1]. ROS can directly damage cells via a number of mechanisms, e.g., by influencing the opening probability of the mitochondrial permeability transition pore [11], by causing lipid peroxidation [1], by activating matrix metalloproteinases [12], or by oxidizing DNA [12]. However, ROS may also damage cells in a more indirect manner: They can, e.g., interact with nitric oxide (NO), fatty acids, or free iron (Fenton reaction). This often results in the formation of even more cytotoxic substances, such as peroxynitrite, peroxyl radicals, and hydroxyl radicals [11]. In addition, ROS can enhance the inflammatory response by the upregulation of chemokines and adhesion molecules $[1,10]$. Thus, the reperfusion phase can be seen as a "double-edged sword" [13]: On one hand, there is a cellular demand for the replenishment of oxygen, while on the other hand, this oxygen results in ROS formation. The paradoxical role of oxygen in the first two phases is called the "oxygen paradox" [9].

The second ROS paradox shows up in a later and more chronic phase of IRI, the post-reperfusion phase. In contrast to their detrimental role in the acute phases, here, ROS affect several tightly regulated processes that lead to an optimal environment for survival: Angiogenesis is induced by ROS through the upregulation or activation of vascular endothelial growth factor (VEGF) and hypoxia-inducible factor
(HIF) $[14,15]$. The proliferation and differentiation of vascular smooth muscle cells (VSMC), needed for vascular remodeling, are also affected by ROS $[14,15]$. These beneficial roles of ROS are also seen during permanent ischemia.

\section{NADPH oxidases as a source of ROS in IRI}

Most sources of ROS (see the "Other sources of ROS in IRI" section) only generate ROS "by accident," i.e., as a byproduct of the metabolism they are involved in or during nonphysiologic conditions, such as ischemia [16-21]. NADPH oxidases stand out from these sources of ROS, as they constitute the only enzyme family with the sole function to produce ROS, not only in disease, but also in physiology [22]. NADPH oxidases are abundantly expressed in the vasculature, where they are emerging as the key producers of ROS [7, 23-26]. Depending on the phase of IRI, NADPH oxidases can be either detrimental or protective. Thus, NADPH oxidases also have a double-edged role, similar to their substrate, oxygen.

Interestingly, several drugs used to treat cardiovascular diseases regulate the expression and activity of NADPH oxidases. For example, statins prevent the translocation of the NADPH oxidase subunit Rac1 to the cell membrane [27]. This translocation is one of the essential steps in the activation of some NOX isoforms [28]. Thus, some of the pleiotropic effects of statins can be attributed to their ability to decrease NADPH oxidase-mediated ROS production [27, 29, 30]. Angiotensin-converting enzyme (ACE) inhibitors and angiotensin receptor blockers (ARB) reduce angiotensin II formation and angiotensin II-mediated AT1 receptor activation, respectively. Since angiotensin II signaling is a potent stimulus for NADPH oxidase expression and activity $[29,30]$, ACE inhibitors and ARB decrease NADPH oxidase expression and activation.

\section{Biochemistry of NADPH oxidases}

NADPH oxidases are multiprotein complexes. Seven isoforms of their catalytic subunits exist, annotated as NOX1-5 and DUOX1-2 (recently also termed as NOX6-7). They contain six or seven transmembrane spanning domains, respectively. They catalyze the electron transport from NADPH to molecular oxygen, thereby producing ROS [7, $22,31,32]$. All isoforms have two heme groups, an FAD and a NADPH binding site [26]. NOX2 was the first described isoform. It was discovered in neutrophils, where it mediates oxidative burst and is thus important for innate host defense [22-24, 28]. In the vasculature, NOX2 is active in almost all vascular wall cells $[33,34]$. In the cardiovascular system, next to NOX2, NOX1, NOX4, and NOX5 are also expressed. The latter, however, is not present in rats and 
mice [24, 28, 32]. NOX1 is expressed in endothelial cells (EC), VSMC, and adventitial fibroblasts [35]. NOX4, the most abundantly expressed isoform, is found in EC and VSMC $[24,35]$. Its expression and activity seem to be especially prominent in the cerebral vasculature [36], with gender-specific differences [37]. NOX5 is located in vascular EC [38] and VSMC [39]. The NOX isoforms not only vary in their expression pattern but also in their subcellular localizations. For example, NOX4, is found in the nucleus and might be present in mitochondria [40], making NOX4 a potential source of mitochondrial ROS. NOX1 colocalizes with caveolin-1 [41], associating it with caveolae and eNOS uncoupling (see below) [42]. Furthermore, the various NOX isoforms require different cytosolic subunits for activity, such as activator and organizer proteins or $\operatorname{Rac} 1[43,44]$. NOX4 stands out from the other NOX isoforms as it is constitutively active and produces $\mathrm{H}_{2} \mathrm{O}_{2}$ as its main product [28]. An important feature of NOX5 is that it does not need any of the cytosolic subunits. Importantly, it is directly activated by calcium through calcium binding to its EF hand motifs [24]. NOX6-7 (formerly called DUOX1-2) play probably no (major) role in the vasculature. Figure 1 and
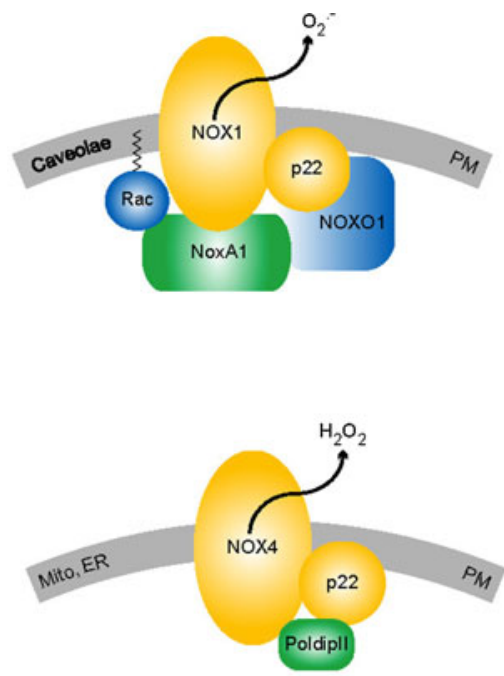

Fig. 1 The four vascular NOX isoforms need different subunits for their activation, have different subcellular localizations, and produce different types of ROS. NOX2 is the first described isoform of the NADPH oxidase family. It consists of a six-transmembrane-spanning catalytic domain. The membrane-bound subunit p22phox and cytosolic subunits p47phox, p67phox, and p40phox need to assemble for NOX2 activation. In addition, the small $\mathrm{G}$ protein Rac binds to this complex. NOX2 is mainly localized in intracellular vesicles, but also in plasma membranes $(P M)$. The basic structure of NOX1 is similar to NOX2. However, NOX1 interacts with the p47phox and p67phox analogs, NOXO1 and NOXA1, although at least in recombinant systems, it is also active upon interaction with p47phox and p67phox (not shown). NOX1 activity also depends on p22phox and Rac. Similar to NOX2, NOX1 is located in the PM. In addition, it was suggested to be located in caveolae. NOX3 appears not to be expressed in the vasculature but
Table 1 give an overview of the characteristics of the isoforms expressed in the cardiovascular system.

Validation of NADPH oxidases as therapeutic targets for IRI

\section{NADPH oxidases during acute ischemia}

NADPH oxidases have been proposed to be oxygen sensors and thus to be involved in the ischemic phase of IRI (Fig. 2) [45-48]. They are also likely to interact with the HIF pathway (see below) [49-55].

Oxygen sensing is the endogenous ability of tissues to respond to changes in oxygen tension. It occurs in specialized cells such as the glomus cells of the carotid body and the neuroepithelial bodies in the lung. While NADPH oxidases are expressed in these tissues [47, 48], a true functional role in oxygen sensing is disputed [47, 48, 56-58]. In this review, we focus on true IRI; discussing the mechanisms of oxygen sensing in more detail is beyond the scope of this review.

First evidence for a role of NADPH oxidases in ischemia comes from studies showing an altered expression on mRNA or protein levels of NADPH oxidases caused by a
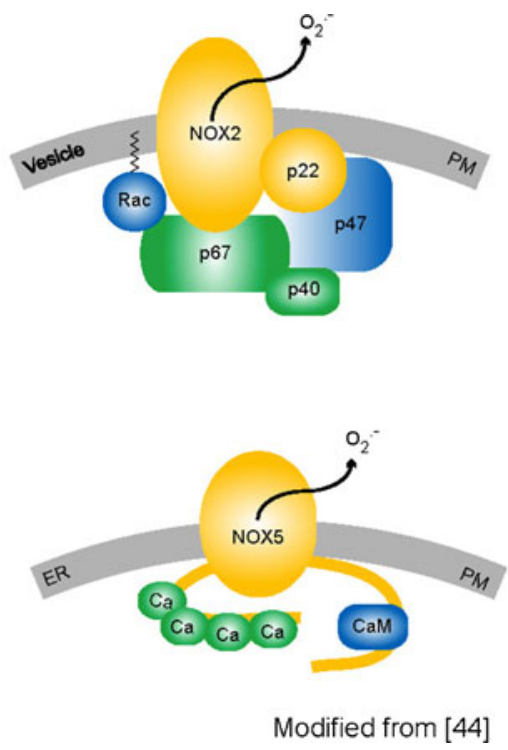

in the inner ear $[28,31]$. NOX4 is different from the other vascular isoforms in that it only interacts with p22phox but does not rely on other cytosolic subunits for its activation. It was suggested that NOX4 is not only located in the plasma membrane, but also in membranes of the endoplasmic reticulum $(E R)$ and in mitochondria. NOX4 is constitutively active, but can be further activated by several factors such as angiotensin or growth factors. PolDip2 has been described as a binding protein that can activate NOX4 [152]. NOX4 has been suggested to also or even predominantly generate hydrogen peroxide $\left(\mathrm{H}_{2} \mathrm{O}_{2}\right)$. NOX5 has mainly been found in the ER in addition to its localization in the PM. It produces superoxide and is active without any subunits. An increase in calcium activates NOX5 mediated by its calcium binding domains, i.e., the $\mathrm{EF}$ hands. In addition, the $\mathrm{C}$ terminus of NOX5 has a calmodulin-binding domain 
change in oxygen tension. In pulmonary artery smooth muscle cells (PASMC), EC, pulmonary epithelial cells, and PC12 cells, a cell line from pheochromocytoma of rat adrenal medulla [51, 53, 54], either NOX1, NOX2, or NOX4 mRNA and protein levels are upregulated during hypoxia. In vivo, an upregulation of NOX4 was also shown in mouse lungs after hypoxia $[51,59]$. Similarly, mRNA levels of the NADPH oxidase subunits $\mathrm{p} 22^{\text {phox }}, \mathrm{p} 47^{\text {phox }}$, and $\mathrm{p} 67^{\text {phox }}$ increased in response to hypoxia in human umbilical vein endothelial cells (HUVEC) [60]. In the brain of rats and mice, upregulation of NOX2, NOX4, and p47phox mRNA levels was reported after stroke induced by ischemia/reperfusion (I/R) [61-63]. An increase in NOX2, NOX4, p22 $2^{\text {phox }}$, and p6 $7^{\text {phox }}$ mRNA was also found after MI in mice [64-66]. Furthermore, NOX4 mRNA and protein levels were upregulated in peripheral muscles after hindlimb ischemia in mice [67]. Taken together, the aforementioned studies indicate that NOX isoforms are upregulated at the mRNA level. However, a concomitant increase at the protein or functional level has not always been reported. Therefore, further studies are necessary.

The effects of hypoxia on NADPH oxidases and reciprocal effects of NADPH oxidases on hypoxic signaling pathways seem to be mediated by different regulatory pathways, some of them involving hypoxia-inducible transcription factors of the HIF family [68]. HIFs are composed of an oxygen-sensitive $\alpha$ subunit and a constitutively expressed $\beta$-subunit also termed aryl hydrocarbon receptor nuclear translocator [69].

Interactions between NADPH oxidases and HIF proteins have been shown for different NOX isoforms and NADPH oxidase subunits $[68,70]$. ROS derived from NADPH oxidases can upregulate HIF-1 $\alpha$ mRNA and protein levels [71]. In VSMC, HIF- $1 \alpha$ is induced by thrombotic factors. This induction and its further activation depend on Rac1 and $\mathrm{p} 22^{\text {phox }}[52,72]$. Further data indicate that NOX2 and NOX4 play a role in regulating HIF- $1 \alpha$ levels in EC, thereby modulating angiogenic activity [73]. In PASMC, NOX4 induced HIF- $1 \alpha$ and HIF- $2 \alpha$ levels by interfering with the activity of the HIF- $\alpha$-modifying prolyl hydroxylases [50]. These data indicate that NADPH oxidases can modulate HIF activity by several mechanisms, including transcriptional upregulation of HIF- $1 \alpha$ through the activation of NFKB [71]. In addition, NADPH oxidases have been reported to mediate posttranslational stabilization of HIF- $1 \alpha$ proteins by interfering with the HIF-degrading machinery [50].

Both transient and stable overexpression of NOX1 in A549 cells resulted in increased HIF-1-dependent target gene expression [53]. Also, increased HIF-1 $\alpha$ protein was found both during hypoxia and normoxia in these NOX1transfected cells [53].

On the other hand, expression of active Rac1 decreased nuclear HIF- $1 \alpha$ levels in HepG2 cells and primary rat hepatocytes under hypoxia [74], while opposite effects were reported in Hep3B cells [75]. The different NOX isoforms/ 


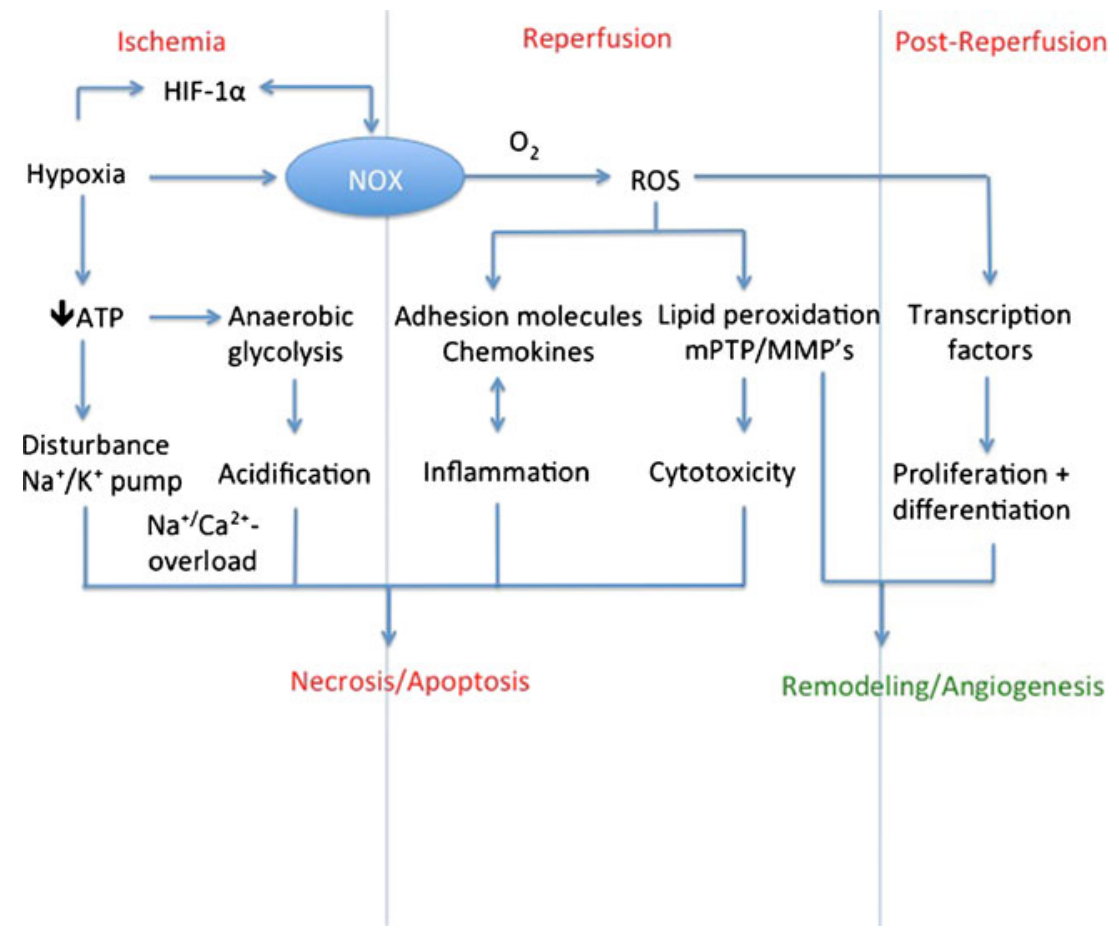

Fig. 2 The role of NADPH oxidases in the three phases of IRI. During the ischemic phase, the lack of oxygen results in decreased ATP production, increasing the calcium concentration, which ultimately results in necrosis. In addition, the drop in oxygen upregulates NADPH oxidases via stimulation of HIF-1 $\alpha$. NADPH oxidases can also activate HIF- $1 \alpha$, initiating a positive feedback loop. When a reintroduction of oxygen occurs during the reperfusion phase, NADPH oxidases produce large amounts of ROS. These ROS then enhance the inflammatory response

subunits might thus have specific roles, and/or the redox sensitivity of different cells and tissues might be specific.

NADPH oxidases not only regulate HIF- $1 \alpha$ and HIF- $2 \alpha$, but HIF can vice versa also affect NADPH oxidases. In mice with a heterozygous defect in HIF- $1 \alpha$ and thus reduced HIF- $1 \alpha$ levels, NOX 2 mRNA and protein did not increase in the cortex and brainstem after exposure to intermittent hypoxia, while in wild-type (WT) mice, NOX2 was upregulated [54]. Fibroblasts from HIF- $1 \alpha$ heterozygous mice had a lower basal HIF-dependent reporter gene activity, and NOX2 mRNA levels did not increase after hypoxia, but they did increase in fibroblasts from WT mice [54]. Similarly, in endothelial-specific HIF- $1 \alpha$ knockout (KO) mice, NOX2 mRNA expression and protein levels were reduced even when adding the NOX2-stimulator urotensin-II [73].

Overexpression of HIF-1 $\alpha$ in PC12 cells also increased NOX2 mRNA and protein levels as well as NADPH oxidase activity after intermittent hypoxia [55]. Importantly, a functional HIF binding site in the proximal promoter of the NOX2 gene was recently identified [73], and thus, NOX2 was added to the list of genuine HIF-1 target genes. As such, HIF-1 can regulate the expression of NOX2 and thereby ROS production by NOX2. For NOX4, a decrease of its by upregulation of adhesion molecules and chemokines, which activate and attract leucocytes. Inflammation and edema ensue. ROS can also have direct cytotoxic effects. Together with the inflammation, this ultimately results in necrosis and apoptosis of cells. ROS production also occurs during the post-reperfusion phase. In this phase, a certain level of ROS is needed to ensure a proper stimulation of angiogenesis via VEGF activating EC and remodeling via the NFKB pathway activating VSMC. This leads to a better environment for tissue survival

mRNA levels in PASMC during hypoxia after treatment of the cells with shRNA against HIF-1 $\alpha$ was reported [51]. Vice versa, overexpression of HIF- $1 \alpha$ resulted in elevated NOX4 mRNA and protein levels. ROS production also increased after overexpression of HIF- $1 \alpha$, but only when NOX4 was present [51]. Similarly to NOX2, a functional HIF binding site was identified in the NOX4 promoter, thus adding also NOX4 to the list of direct HIF target genes [51].

These findings suggest that ROS-dependent activation of HIF can induce the expression of several NADPH oxidase subunits under normoxic conditions, thus promoting ROSmediated signaling pathways. Under low oxygen conditions, such as ischemia, the rapid stabilization and activation of HIF may be the primary event responsible for the upregulation of NADPH oxidases. This process may help cells and tissues to adapt at least partially to the decreased substrate availability under these conditions, thereby also allowing a certain restoration of ROS levels under hypoxia. However, whether NADPH oxidases can also be activated under hypoxia without concomitant increase in subunit availability is not clear and precise mechanisms and interactions of NADPH oxidase-derived ROS under these conditions still need to be elucidated. 


\section{NADPH oxidases during reperfusion}

Upon reintroduction of oxygen, NADPH oxidases are believed to generate large amounts of ROS, which have direct cytotoxic effects [11, 12] (Fig. 2). For example, after I/R of the lung or the brain, lipid peroxidation, protein nitration, and oxidative DNA damage were smaller in NOX2 KO [76] or $\mathrm{p} 47^{\text {phox }}$ KO mice compared to WT mice [77, 78]. Similar results were found when apocynin, an unspecific NADPH oxidase inhibitor [30, 79], was applied to WT mice [76, 78]. Apocynin and diphenylene iodonium (DPI), another unspecific NADPH oxidase inhibitor, also reduced the increases in lipid peroxidation, cell death, and apoptosis after I/R in $\mathrm{H} 9 \mathrm{c} 2$ cells $[80,81]$. However, these results should be interpreted with caution because of the lack of specificity of these inhibitors: apocynin has antioxidant properties [79] and DPI is a general flavoprotein inhibitor [82]. The more specific NADPH oxidase inhibitor VAS2870 given to WT mice 2 and $12 \mathrm{~h}$ after cerebral I/R, which was induced by transient middle cerebral artery occlusion, decreased infarct size, ROS levels, tissue nitration, apoptosis, and brain edema. VAS2870 also improved the functional outcome in WT mice after the induction of ischemic strokes [62]. NOX4 KO mice showed the same decreases in damage as VAS2870-treated WT mice, while treatment of NOX4 KO mice with VAS2870 did not have an additional protective effect [62]. This strongly suggests that NOX4 contributes to cerebral IRI. Together, these studies show that NADPH oxidases-derived ROS, particularly NOX4, are likely to be involved in the direct cytotoxic effects of IRI in the brain.

Evidence for the role of other NOX isoforms in cerebral IRI is contradictory. No effect of NOX1 or NOX2 in brain IRI was found in the study mentioned above [62]. Two other studies showed no role [83] or a detrimental role [84], respectively, of NOX1 in stroke. Data concerning the role of NOX2 are also conflicting [62, 76, 77, 84-87]. For a more detailed discussion of the role of NADPH oxidases in brain $\mathrm{I} / \mathrm{R}$, we refer to [88].

NADPH oxidases can also indirectly cause damage by enhancing the inflammatory response [22]. Neutrophils, which express NOX2, are the primary source of ROS after heart I/R in dogs [89]. Further, neutrophil infiltration was reduced after brain $\mathrm{I} / \mathrm{R}$ in NOX2 $\mathrm{KO}$ mice compared to WT mice. Similarly, neutrophil infiltration was attenuated in the lungs of $\mathrm{p} 47^{\text {phox }} \mathrm{KO}$ mice or of mice treated with apocynin $[76,78]$. However, again, apocynin is not specific for NADPH oxidases. Furthermore, after lung $I / R$, proinflammatory cytokine levels including TNF- $\alpha$, IL- 6 , IL- $1 \beta$, and MCP-1 in lungs were lower in $\mathrm{p} 47^{\text {phox }} \mathrm{KO}$ mice compared to WT mice [78]. This was also observed in the brain after I/ $\mathrm{R}$ [76]. Here, the ischemic stroke induced the disruption of the blood-brain barrier (BBB), which contributes to inflammation via increased permeability and subsequent tissue swelling after brain $\mathrm{I} / \mathrm{R}$. This BBB disruption was reduced in NOX2 KO mice compared to WT mice [86].

In an isolated perfused lung $\mathrm{I} / \mathrm{R}$ model, edema and vascular permeability were reduced in lungs from NOX2 KO mice, but neither in lungs from NOX1 KO mice nor in NOX4 KO mice [90]. Together, these data suggest a role of NOX 2 or $\mathrm{p} 47^{\text {phox }}$ in the inflammatory reaction and chemotaxis during IRI. The regulation of different cytokines in different organs suggests a cell-specific or organ-specific effect of NOX2. With respect to the other NOX isoforms, no solid data on their involvement in inflammation and chemotaxis after IRI are available.

\section{NADPH oxidases during post-reperfusion and chronic ischemia}

ROS are not only toxic during acute IRI, they are also key signaling molecules in pathways mediating cell proliferation and differentiation [7, 22, 91-93], which are needed for both angiogenesis and remodeling (Fig. 2). During the postreperfusion period or during chronic ischemia, NADPH oxidases might thus have a protective role, showing the second edge of the NADPH oxidase sword [94-97]. On one hand, ROS can mediate autophosphorylation of vascular endothelial growth factor receptor 2 (VEGFR2), which leads to the activation of downstream signaling pathways [96]. In addition, by interacting with HIF-1 $\alpha$, ROS can activate VEGF and other targets, which protect and activate vascular proliferative responses such as plasminogen activator inhibitor-1 (PAI-1) $[68,70,71]$.

On the other hand, VEGF can activate NADPH oxidases via Rac1, leading to increased ROS production [98]. This feedback loop ultimately results in increased VEGF-induced angiogenesis. In nonvascular cells, there is also a negative feedback loop involved, in which Rac1 inhibits HIF-1 and PAI-1 and thus decreases angiogenesis [74].

The nonspecific NADPH oxidase inhibitor, DPI, and the antioxidant, $\mathrm{N}$-acetylcysteine, decreased VEGF-induced ROS levels in HUVEC, as did NOX2 antisense constructs [98]. $\mathrm{p} 47^{\text {phox }}$ downregulation in HUVEC also led to decreased VEGF-mediated phosphorylation of downstream mediators [99]. VEGF-induced neovascularization in a sponge implant model was also reduced in NOX2 KO mice compared to WT mice [98]. Together, these data clearly point to a role of NADPH oxidases in the VEGF signaling pathway in vascular cells at several levels. However, the importance of NOX2 for angiogenic responses is not limited to VEGF signaling. Recently, it was reported that the vasoactive peptide urotensin-II can also induce angiogenesis, and this response was inhibited in vitro by downregulating NOX2 in EC using shRNA. Similarly, vascular sprouting into a Matrigel plug was disrupted in NOX2 $\mathrm{KO}$ mice, but not in WT mice [73]. 
After hindlimb ischemia, flow recovery and capillary density were reduced in NOX2 KO mice [100, 101]. However, there is also evidence for a normal collateral growth in NOX2 KO mice, with only a dysfunction of the newly formed vessels, resulting in compromised perfusion [102]. In addition, when adding oxidative stress triggers, such as smoking or diabetes, the impairment of new vascularization was less pronounced in NOX2 KO mice compared to WT mice $[103,104]$. Thus, while NOX2 clearly seems to be involved in promoting angiogenesis in vivo, it is the specific environment (i.e., oxidative stress or not) that finally determines the overall impact of NOX2 on these responses.

During remodeling in the chronic phase of IRI, NOX2 seems to play a detrimental role. NOX2 or $\mathrm{p} 47^{\text {phox }} \mathrm{KO}$ mice subjected to MI displayed less dilatation of the left ventricle, less hypertrophy, and less interstitial fibrosis along with an increased survival after 4 weeks [64, 65]. Interestingly, infarct sizes did not differ between KO and WT mice both after $24 \mathrm{~h}$ and 4 weeks [64, 65]. Others did not find any difference between NOX2 KO and WT mice in infarct size, apoptosis, collagen content, or inflammation after MI [66, 105]. However, some studies neither used littermates as control mice nor sham-operated animals. This is relevant when interpreting these results. Furthermore, differences in mouse strains can influence heart remodeling [106]. Also, $\mathrm{p} 47^{\text {phox }} \mathrm{KO}$ and $\mathrm{p} 47^{\text {phox }}$ heterozygous mice had similar infarct sizes and left ventricular functions $24 \mathrm{~h}$ after I/R of the heart [107]. However, $24 \mathrm{~h}$ of reperfusion in the heart can be rather regarded as an acute reperfusion phase; thus, these results suggest that there is no role for NOX2 and $\mathrm{p} 47^{\text {phox }}$ in acute heart IRI. Rather, there may be an effect in the post-reperfusion phase. Although the data are contradictory, most studies suggest a rather detrimental role of NOX2 in long-term remodeling after MI.

NOX1 has been shown to be involved in angiogenesis in tumors [108], but data in I/R models are missing. NOX1overexpressing transgenic mice showed an increased hypertrophy of VSMC in response to angiotensin II [109]. Moreover, NOX1 may be involved in cell growth and transformation, not only in the vasculature but also in tumor-forming cells $[110,111]$.

For NOX4, data suggest a protective role in the chronic phase of IRI. siRNA against NOX4 reduced tube formation and wound healing responses in HMEC and HUVEC and also inhibited both basal and VEGF-induced cell migration or proliferation $[67,112]$. NOX4 overexpression increased these responses [67, 112]. In line, similar responses of cell migration and proliferation were found after overexpressing or silencing NOX4 in human and bovine EC grown on Matrigel [67]. However, studies using siRNA against NOX4 should be interpreted with caution, since not all siRNAs specifically downregulate NOX4 and some may also affect other NOX isoforms [113].
In mice injected with adenoviral NOX4 into the hindlimb, blood flow was increased after ligation of the femoral artery compared to nontreated animals [67]. Accordingly, blood flow restoration in NOX4 KO mice was reduced after hindlimb ischemia [114]. Furthermore, aortas of endothelial-specific NOX4 transgenic mice displayed increased sprouting ex vivo [67]. Thus, a protective role for NOX4 in angiogenesis during chronic ischemia is likely.

In addition, an involvement of NOX4 in the regulation of VSMC growth and differentiation was suggested [91, 93]. In wound healing and embryogenesis, maintenance of VSMC differentiation might be a beneficial effect of NOX4 [91]. However, in IRI and cardiac pressure overload, NOX4 in cardiomyocytes and cardiac fibroblasts may have a more ambivalent role: They seem to stimulate proliferation and differentiation of cardiac fibroblasts into myofibroblasts, which may lead to fibrosis, cardiac remodeling, and heart failure $[92,115]$. In human PASMC, NOX4 also mediated proliferation in response to hypoxia, but also to factors such as transforming growth factor $\beta 1$ or urotensinII, which can contribute to vascular remodeling in different disease states [51, 116, 117]. Moreover, hypertrophic stimuli such as angiotensin II and pressure overload increased NOX4 expression in cardiac myocytes [118]. Aged mice overexpressing NOX4 in the heart showed increased fibrosis and apoptosis of cardiomyocytes [118]. Interestingly, overexpression of HIF- $1 \alpha$ increased proliferation in PASMC, but not when NOX4 was depleted by shRNA [51]. Thus, an additional role of HIF- $1 \alpha$ in the VSMC proliferative response seems likely. Altogether NOX4 seems to be involved in regulating the growth and differentiation of VSMC and cardiac cells, which in the post-reperfusion phase might lead to remodeling and formation of fibrosis. Unfortunately, there are no in vivo data on the effect of NOX 4 on the long-term remodeling after IRI. The in vivo and in vitro studies discussed are summarized in Tables 2 and 3 , respectively.

\section{Other sources of ROS in IRI}

As already mentioned, other sources of ROS distinct from NADPH oxidases generate ROS under nonphysiological conditions. This indicates that these sources might also play a role in IRI. For example, xanthine oxidoreductase (XOR) catalyses the formation of xanthine and uric acid from hypoxanthine. It can exist in two different forms, xanthine dehydrogenase that transfers electrons to $\mathrm{NAD}^{+}$and xanthine oxidase, which cannot bind $\mathrm{NAD}^{+}$, thus transferring electrons directly to molecular oxygen [119]. Under conditions of inflammation or oxidative stress, xanthine dehydrogenase can be posttranslationally modified to the ROSproducing xanthine oxidase $[20,119]$. The evidence for a 
Table 2 In vivo studies on the role of NADPH oxidases in IRI

\begin{tabular}{|c|c|c|c|c|c|c|c|c|}
\hline \multicolumn{9}{|l|}{ Heart } \\
\hline \multirow[t]{2}{*}{ Animal model } & \multirow[t]{2}{*}{ Ischemic model } & \multirow{2}{*}{$\begin{array}{l}\text { Time point } \\
\text { investigated }\end{array}$} & \multicolumn{5}{|l|}{ Outcomes } & \multirow[t]{2}{*}{ Reference } \\
\hline & & & $\begin{array}{l}\text { Cardiac } \\
\text { dilatation }\end{array}$ & $\begin{array}{l}\text { Cardiac } \\
\text { dysfunction }\end{array}$ & Infarct size & Survival & Inflammation & \\
\hline $\mathrm{p} 47^{\text {phox }} \mathrm{KO}$ vs WT mice & LAD ligation & 4 week & $\downarrow$ & $\downarrow$ & $\varnothing$ & $\uparrow$ & n.a. & [64] \\
\hline $\begin{array}{l}\text { p } 47^{\text {phox }} \mathrm{KO} \text { vs } \mathrm{p} 47^{\text {phox }} \\
\text { Het mice }\end{array}$ & $\begin{array}{l}\text { Transient LAD } \\
\text { ligation }(30 \mathrm{~min})\end{array}$ & $24 \mathrm{~h}$ & $\varnothing$ & $\varnothing$ & $\varnothing$ & n.a. & $\uparrow$ & [107] \\
\hline NOX2 KO vs WT mice & LAD ligation & 8 week & $\varnothing$ & $\varnothing$ & $\varnothing$ & $\downarrow$ & n.a. & [105] \\
\hline NOX2 KO vs WT mice & LAD ligation & 4 week & $\downarrow$ & $\downarrow$ & $\varnothing$ & $\varnothing$ & n.a. & [65] \\
\hline NOX2 KO vs WT mice & LAD ligation & 4 week & n.a. & n.a. & $\varnothing$ & n.a. & $\varnothing$ & [66] \\
\hline \multicolumn{9}{|l|}{ Brain } \\
\hline \multirow[t]{2}{*}{ Animal model } & \multirow[t]{2}{*}{ Ischemic model } & \multirow{2}{*}{$\begin{array}{l}\text { Time point } \\
\text { investigated }\end{array}$} & \multirow{2}{*}{$\begin{array}{l}\text { Outcomes } \\
\text { Infarct size }\end{array}$} & & & \multirow{2}{*}{\multicolumn{2}{|c|}{ BBB dysfunction }} & \multirow[t]{2}{*}{ Reference } \\
\hline & & & & $\begin{array}{l}\text { Neurological } \\
\text { outcome }\end{array}$ & Inflammation & & & \\
\hline NOX1 KO vs WT mice & tMCAO (30 min) & $24 \mathrm{~h}$ & $\varnothing$ & $\varnothing$ & n.a. & n.a. & & [83] \\
\hline NOX1 KO vs WT mice & tMCAO (60 min) & $24 \mathrm{~h}$ & $\varnothing$ & $\varnothing$ & n.a. & n.a. & & [62] \\
\hline NOX1 KO vs WT mice & tMCAO (60 min) & & $\downarrow$ & $\uparrow$ & n.a. & $\downarrow$ & & [84] \\
\hline NOX2 KO vs WT mice & tMCAO (60 min) & 24 and $72 \mathrm{~h}$ & $\downarrow$ & n.a. & $\downarrow$ & n.a. & & [77] \\
\hline NOX2 KO vs WT mice & tMCAO (75 min) & 24 and $72 \mathrm{~h}$ & $\downarrow$ & $\uparrow$ & $\downarrow$ & n.a. & & [76] \\
\hline NOX2 KO vs WT mice & tMCAO (120 min) & $1 / 2 / 24 \mathrm{~h}$ & $\begin{array}{l}24 \mathrm{~h}, \downarrow ; 2 \mathrm{~h}, \\
\varnothing\end{array}$ & n.a. & n.a. & $1 \mathrm{~h}, \downarrow$ & & [86] \\
\hline NOX2 KO vs WT mice & tMCAO (60 min) & $24 \mathrm{~h}$ & $\varnothing$ & $\varnothing$ & n.a. & n.a. & & [62] \\
\hline NOX2 KO vs WT mice & tMCAO (25 min) & $72 \mathrm{~h}$ & $\downarrow$ & n.a. & n.a. & n.a. & & {$[150]$} \\
\hline NOX2 KO vs WT mice & tMCAO (120 min) & $24 \mathrm{~h}$ & $\downarrow$ & n.a. & $\varnothing$ & n.a. & & [87] \\
\hline \multirow[t]{3}{*}{ NOX4 KO vs WT mice } & tMCAO (60 min) & $24 \mathrm{~h}$ & $\downarrow$ & $\uparrow$ & n.a. & $\downarrow$ & & \multirow[t]{3}{*}[62]{} \\
\hline & pMCAO & $24 \mathrm{~h}$ & $\downarrow$ & $\uparrow$ & n.a. & n.a. & & \\
\hline & PT & $24 \mathrm{~h}$ & $\downarrow$ & n.a. & n.a. & n.a. & & \\
\hline $\begin{array}{l}\text { WT mice treated with } \\
\text { VAS } 2870\end{array}$ & TMCAO & $24 \mathrm{~h}$ & $\downarrow$ & $\uparrow$ & n.a. & n.a. & & \\
\hline \multicolumn{9}{|l|}{ Hindlimb } \\
\hline \multirow[t]{2}{*}{ Animal model } & \multirow[t]{2}{*}{ Ischemic model } & \multirow[t]{2}{*}{ Time endpoint } & Outcomes & \multirow{2}{*}{\multicolumn{2}{|c|}{ Capillary density }} & & & \multirow[t]{2}{*}{ Reference } \\
\hline & & & $\begin{array}{l}\text { Blood flow } \\
\text { recovery }\end{array}$ & & & Ischemic & muscle injury & \\
\hline NOX1 KO vs WT mice & FA ligation & 2 weeks & $\uparrow$ & n.a. & & n.a. & & [114] \\
\hline NOX2 KO vs WT mice & FA excision & 2 weeks & $\downarrow$ & n.a. & & $\uparrow$ & & [102] \\
\hline NOX2 KO vs WT mice & \multirow[t]{2}{*}{ FA ligation } & 3 weeks & $\downarrow$ & $\downarrow$ & & n.a. & & [104] \\
\hline $\begin{array}{l}\text { Diabetic NOX2 KO vs } \\
\text { diabetic WT mice }\end{array}$ & & & $\uparrow$ & $\uparrow$ & & n.a. & & \\
\hline NOX2 KO vs WT mice & FA excision & 2 weeks & $\uparrow$ & $\uparrow$ & & n.a. & & [103] \\
\hline $\begin{array}{l}\text { NOX2 KO vs WT mice after } \\
\text { chronic smoke exposure }\end{array}$ & & & $\uparrow$ & $\uparrow$ & & n.a. & & \\
\hline NOX2 KO vs WT mice & FA ligation & 2 weeks & $\downarrow$ & n.a. & & n.a. & & [114] \\
\hline NOX2 KO vs WT mice & FA excision & 1 week & $\downarrow$ & $\downarrow$ & & n.a. & & [101] \\
\hline NOX2 KO vs WT mice & FAV excision & 2 weeks & $\downarrow$ & n.a. & & n.a. & & [100] \\
\hline $\begin{array}{l}\text { WT mice after adenoviral } \\
\text { NOX4 injection vs WT } \\
\text { mice }\end{array}$ & FA ligation & 4 weeks & $\uparrow$ & $\uparrow$ & & n.a. & & [67] \\
\hline NOX4 KO vs WT mice & FA ligation & 2 weeks & $\uparrow$ & n.a. & & $\uparrow$ & & [114] \\
\hline $\begin{array}{l}\text { Inducible NOX4 KO vs WT } \\
\text { mice }\end{array}$ & & & $\uparrow$ & n.a. & & $\uparrow$ & & \\
\hline Lung & & & & & & & & \\
\hline Animal model & Ischemic model & $\begin{array}{l}\text { Time point } \\
\text { investigated }\end{array}$ & $\begin{array}{l}\text { Outcomes } \\
\text { Edema }\end{array}$ & $\mathrm{Kfc}$ & & Pulmonar & y function & Reference \\
\hline NOX1 KO vs WT mice & Isolated perfused & $30 / 60 / 90 \mathrm{~min}$ & $\varnothing$ & $\varnothing$ & & n.a. & & {$[90]$} \\
\hline NOX2 KO vs WT mice & lung ischemia & & $\downarrow$ & $\downarrow$ & & n.a. & & \\
\hline NOX4 KO vs WT mice & (90 min) & & $\varnothing$ & $\varnothing$ & & n.a. & & \\
\hline p $47^{\text {phox }}$ KO vs WT mice & $\begin{array}{l}\text { Lung hilar ligation } \\
\text { (60 min) }\end{array}$ & $120 \mathrm{~min}$ & $\downarrow$ & n.a & & $\uparrow$ & & [78] \\
\hline
\end{tabular}

n.a. not applicable, $B B B$ blood-brain barrier, $F A$ femoral artery, $L A D$ left anterior descending coronary artery, $p M C A O$ permanent middle cerebral artery occlusion, $t M C A O$ transient middle cerebral artery occlusion, $\varnothing$ no change 
Table 3 In vitro studies on the role of NAPDH oxidases in IRI

\begin{tabular}{|c|c|c|c|}
\hline Cell/tissue & Treatment & Outcome & Reference \\
\hline \multicolumn{4}{|c|}{ ROS production and NOX expression } \\
\hline H9c2 cardiac cells & $\begin{array}{l}\mathrm{I} / \mathrm{R} \\
\mathrm{I} / \mathrm{R}+\mathrm{DPI} \text { or apocynin }\end{array}$ & $\begin{array}{l}\uparrow \mathrm{ROS}, \uparrow \mathrm{p} 47^{\text {phox }} \text { protein, } \uparrow \text { NOX } 2 \text { protein } \\
\downarrow \text { ROS increase }\end{array}$ & {$[80]$} \\
\hline H9c2 cardiac cells & $\begin{array}{l}\text { Metabolic inhibition (ischemia) } \\
\text { Metabolic inhibition+DPI or } \\
\text { apocynin }\end{array}$ & $\begin{array}{l}\uparrow \operatorname{ROS}, \uparrow \text { NOX } 2 \text { mRNA, } \uparrow \text { apoptosis } \\
\downarrow \text { ROS increase, } \downarrow \text { apoptosis }\end{array}$ & [81] \\
\hline $\begin{array}{l}\text { Human PASMC } \\
\text { HepG2 cells }\end{array}$ & $\begin{array}{l}\text { Hypoxia } \\
\text { Hypoxia and overexpression HIF-1 } \alpha\end{array}$ & $\begin{array}{l}\uparrow \text { NOX4 mRNA and protein and HIF- } 1 \alpha \text { mRNA and protein } \\
\uparrow \text { Cell proliferation and ROS production }\end{array}$ & {$[51]$} \\
\hline HEK293 & $\begin{array}{l}\text { Hypoxia, overexpression HIF-1 } \alpha \\
\text { and depletion NOX4 with shRNA }\end{array}$ & $\downarrow$ of increased proliferation and ROS production & \\
\hline \multicolumn{4}{|l|}{ Angiogenesis } \\
\hline $\begin{array}{l}\text { NIH } 3 \text { T3 cells } \\
\text { DU-145 }\end{array}$ & $\begin{array}{l}\text { Transfection of cells with NOX1, } \\
\text { then injection into athymic mice }\end{array}$ & $\begin{array}{l}\uparrow \text { VEGF expression, } \uparrow \mathrm{H}_{2} \mathrm{O}_{2} \text { production } \\
\uparrow \text { Growth of tumours with more vascularization }\end{array}$ & [108] \\
\hline NIH-3T3 cells & $\begin{array}{l}\text { Transfection of cells with NOX1, } \\
\text { then overexpression catalase }\end{array}$ & $\begin{array}{l}\uparrow \text { Cell proliferation, } \uparrow \mathrm{H}_{2} \mathrm{O}_{2} \text { production, } \\
\text { Reversion of NOX1 induced phenotype }\end{array}$ & {$[110]$} \\
\hline Human and bovine EC & $\begin{array}{l}\text { Adenoviral overexpression or } \\
\text { knockdown NOX4 }\end{array}$ & $\begin{array}{l}\uparrow \text { Tube formation in overexpressing, } \downarrow \text { tube formation in } \\
\text { knockdown cells }\end{array}$ & {$[67]$} \\
\hline $\begin{array}{l}\text { Aortas from EC-specific } \\
\text { NOX4 Tg and WT mice }\end{array}$ & - & $\uparrow$ Capillary sprouting in $\mathrm{Tg}$ aortas & \\
\hline $\begin{array}{l}\text { HMEC and HUVEC } \\
\text { HMEC }\end{array}$ & $\begin{array}{l}\text { siRNA to NOX4 } \\
\text { Adenoviral transfection NOX4 }\end{array}$ & $\begin{array}{l}\downarrow \text { Tube formation and } \downarrow \text { wound healing } \\
\downarrow \text { EC migration and proliferation }\end{array}$ & [112] \\
\hline & & $\downarrow$ Tube formation but $\uparrow$ wound healing & \\
\hline HUVEC & NOX2 antisense & $\downarrow$ VEGF induced ROS production, proliferation, and migration & [98] \\
\hline HCAEC/HUVEC & $\mathrm{p} 47^{\text {phox }}$ siRNA & $\downarrow$ VEGF mediated phosphorylation of VEGFR2 & [99] \\
\hline $\begin{array}{l}\text { Human endothelial cells } \\
\text { Mouse vena cava explants }\end{array}$ & $\begin{array}{l}\text { Urotensin } \\
\text { Urotensin in NOX2 depleted cells } \\
\text { Urotensin }\end{array}$ & $\begin{array}{l}\uparrow \text { Formation capillary like structures in Matrigel } \\
\downarrow \text { Formation capillary like structures in Matrigel } \\
\uparrow \text { Sprouting in Matrigel }\end{array}$ & [73] \\
\hline \multicolumn{4}{|l|}{ Remodeling } \\
\hline $\begin{array}{l}\text { VSMC from aortas of SD } \\
\text { rats }\end{array}$ & NOX4 siRNA/antisense & $\begin{array}{l}\text { High NOX4 mRNA in differentiating cells, low NOX4 in } \\
\text { dedifferentiating cells } \\
\text { Low NOX } 1 \text { mRNA in differentiating cells, high NOX1 in } \\
\text { dedifferentiating cells } \\
\downarrow \text { Differentiation markers and } \downarrow \text { contractile type stress fibers }\end{array}$ & [91] \\
\hline \multirow[t]{2}{*}{$\begin{array}{l}\text { Human primary cardiac } \\
\text { fibroblasts }\end{array}$} & $\begin{array}{l}\text { TGF- } \beta 1 \\
\text { NOX4 siRNA }\end{array}$ & $\begin{array}{l}\uparrow \text { NOX } 4 \text { mRNA, } \varnothing \text { NOX } 1, \text { NOX } 2 \text { and NOX } 5 \text { mRNA } \\
\downarrow \text { Basal and TGF- } \beta 1 \text { stimulated ROS production, } \downarrow \text { SM } \alpha \text {-actin } \\
\text { mRNA and protein }\end{array}$ & [92] \\
\hline & NOX5 siRNA & $\varnothing$ Basal and TGF- $\beta 1$ stimulated ROS production & \\
\hline $\begin{array}{l}\text { Aortic VSMC from NOX1 } \\
\text { Tg and WT mice }\end{array}$ & AT-II & $\begin{array}{l}\uparrow \text { ROS production in } \mathrm{Tg} \text {, blood pressure elevation in vivo higher in } \\
\mathrm{Tg} \text {, greater hypertrophy (aortic medial thickness) in } \mathrm{Tg}\end{array}$ & [109] \\
\hline Mouse ESC & siRNA against NOX4, shRNA & $\downarrow$ Spontaneously beating EB's & {$[151]$} \\
\hline $\begin{array}{l}\text { Neonatal mouse } \\
\text { cardiomyocytes }\end{array}$ & against NOX4 siRNA & Impaired cardiac myofibrillogenesis & \\
\hline $\begin{array}{l}\text { Neonatal rat } \\
\text { cardiomyocytes }\end{array}$ & AT-II, TAC, and aging & $\uparrow$ NOX4 protein expression & [118] \\
\hline $\begin{array}{l}\text { Cardiomyocytes from } \\
\text { mice }\end{array}$ & NOX4 overexpression & Cell size $\varnothing, \uparrow$ apoptosis in overexpressing cells & \\
\hline Human PASMC & $\begin{array}{l}\text { Urotensin-II } \\
\text { Urotensin-II and antisense vectors } \\
\text { against p22phox and NOX4 }\end{array}$ & $\begin{array}{l}\uparrow \mathrm{p} 22^{\text {phox }} \text { and NOX4 protein expression, } \uparrow \text { ROS production, } \downarrow \text { of } \\
\text { increased ROS production }\end{array}$ & {$[116]$} \\
\hline Human PASMC & $\begin{array}{l}\text { TGF- } \beta 1 \\
\text { TGF- } \beta 1 \text { and siRNA against NOX4 }\end{array}$ & $\begin{array}{l}\uparrow \text { NOX4 mRNA and protein expression and ROS production } \\
\downarrow \text { TGF- } \beta 1 \text { induced proliferation }\end{array}$ & {$[117]$} \\
\hline
\end{tabular}

AT-II angiotensin II, DU145 epithelial cell line derived from human prostate tumor, EB embryoid bodies, ESC embryonic stem cells, HEK293 human embryonic kidney cells, HCAEC human coronary artery endothelial cells, HepG2 human hepatoblastoma cells, HMEC human microvascular endothelial cells, HUVEC human umbilical vein endothelial cells, NIH $3 T 3$ cells mouse embryonic fibroblasts, PASMC pulmonary artery smooth muscle cells, $S D$ rats Sprague-Dawley rats, siRNA short interference RNA, shRNA short hairpin RNA, riRNA ribosomal RNA, TAC transient aortic constriction, VEGF vascular endothelial growth factor, VSMC vascular smooth muscle cells, $\varnothing$ no change 
role of XOR in IRI is controversial, showing both positive and negative roles as reviewed in [16, 20, 119].

NO synthase catalyses the formation of NO from L-arginine, using tetrahydrobiopterin $\left(\mathrm{BH}_{4}\right)$ as an essential, redoxsensitive cofactor. NOS, too, can have double-edged roles within the vasculature: $\mathrm{NO}$ is beneficial by mediating, for example, vasorelaxation, anticoagulant, and antiproliferative properties [10]. However, during IRI, ROS uncouple NOS by oxidizing $\mathrm{BH}_{4}[120]$. NOS itself then produces ROS instead of NO [10, 12, 121]. In addition, NO can react with superoxide to form toxic peroxynitrite [122, 123], causing further cell and tissue damage.

Mitochondria have also been described as being major contributors to ROS production in IRI, especially in the heart [17, 124-127]. Mitochondria form ROS via electron leakage from the electron transport chain during oxidative phosphorylation at different complexes [128] or via less common ways involving monoamine oxidases or p66Shc protein [18]. Similar to the case of NOS, ROS produced by mitochondria or by other sources can lead to a further increased production of ROS: ROS induced ROS release $[129,130]$. Mitochondrial ROS have been shown to also play a role in ischemic preconditioning $[131,132]$.

Interplay between different sources of ROS can also be one of the mechanisms contributing to IRI $[11,22,128]$. NOX4, for example, has been shown to localize in mitochondria, indicating that NOX4 might produce mitochondrial ROS [40]. The ROS produced by NADPH oxidases can then trigger mitochondrial dysfunction, leading to increased ROS production and, vice versa, ROS produced by mitochondria can activate NADPH oxidases. This has recently been reviewed in more detail elsewhere [128].

Nevertheless, it has yet to be established which source(s) of ROS are the pathologically relevant ones in IRI. However, again, NADPH oxidases are the only enzymes with the sole function of generating ROS. Therefore, targeting NADPH oxidases seems a new promising therapeutic strategy, which seems superior compared to using antioxidants, as will be discussed in the following section.

\section{Therapeutic strategies}

\section{Antioxidants}

As ROS and oxidative stress are likely major players in IRI, attempts to prevent and treat related disorders with antioxidant supplements seemed plausible. Indeed, many clinical trials testing the effects of antioxidant application have been performed.

Some rather small clinical trials tested the acute or subacute therapeutic effects of antioxidants in patients with I/Rrelated disorders, with conflicting results. For example, in patients undergoing aortic cross-clamping, oral supplementation of vitamin E ( $60 \mathrm{mg}$ for 8 days presurgery) prevented the overproduction of ROS and diminished muscle damage in the lower limbs [133]. However, such a preventive intervention is, by definition, excluded in post-infarct or poststroke therapies. Nevertheless, in patients with diabetes, but not in nondiabetic patients, a reduction in 30-day mortality after acute MI was found when patients were treated with high doses of vitamin C (1,000 mg intravenously [IV] in $12 \mathrm{~h}, 400 \mathrm{mg}$ orally) and vitamin E (200 mg, two times daily) for 30 days [6]. In contrast, human superoxide dismutase (IV bolus of $10 \mathrm{mg} / \mathrm{kg}$ followed by infusion of $0.2 \mathrm{mg} / \mathrm{kg} / \mathrm{min}$ for $60 \mathrm{~min}$ ) did not show any effect after acute $\mathrm{MI}$ in patients undergoing percutaneous transluminal coronary angioplasty [134]. In smokers with MI, oral supplementation of vitamin E (50 mg daily) did not reduce the incidence of recurrent MI [135]. Alarmingly, the administration of vitamin C ( $2 \mathrm{~g}$ IV $2 \mathrm{~h}$ prior to surgery) in patients undergoing elective $\mathrm{I} / \mathrm{R}$ (aortic clamping) promoted ironinduced oxidative lipid damage via a Fenton-type reaction. The subsequent release of lactate dehydrogenase into the systemic circulation may have catalyzed the formation of second-generation radicals implicated in the regulation of vascular permeability and angiogenesis [136]. The reasons for the conflicting results are not known, but may be caused by the use of different antioxidants, doses, and timing as well as patient collectives. Nevertheless, as these studies only included relatively small patient numbers, they rather have a pilot character.

Many large and long trials tested antioxidant supplements for primary and secondary prevention of $\mathrm{I} / \mathrm{R}$ events. Despite the huge patient numbers, study results are conflicting $[3,5$, $6,135,137,138]$. However, several meta-analyses suggest that the application of antioxidants does not improve cardiovascular mortality and morbidity. In contrast, untargeted supplementation of antioxidants may even be harmful [5, $27,29,30,139]$. Thus, although ROS play an important role in IRI, antioxidants failed to prevent related disorders. Several explanations for this failure have been proposed. For example, antioxidants given orally might not penetrate into the vascular wall; scavenging of radicals can convert antioxidants to radicals themselves exerting pro-oxidant effects; and the timing of the application might not be right, since ROS already play a role in the initiation of cardiovascular diseases [27, 139]. Furthermore, antioxidants - if they reach the target tissue - cannot distinguish between good and bad ROS.

Thus, unraveling the role of ROS and their sources at different time points in IRI is crucial for designing the optimal therapeutic approach. Preventing the formation of disease-triggering ROS at the right time, instead of scavenging them after they have been formed, seems a better therapeutic approach. 
NADPH oxidases as therapeutic targets in IRI

NADPH oxidases are crucial players in all phases of IRI. Thus, interfering with the NADPH oxidase function is a promising strategy for treating IRI. However, important issues need to be considered: First, timing is likely to be crucial, since NADPH oxidases and ROS play different roles, depending on the time course of IRI. Second, isoform-specific differences or organ/cell-specific effects have to be taken into account. Third, the amount of ROS is important, since low amounts of ROS are needed for physiologic functions such as regulation of cell growth and differentiation [11, 12], whereas increased levels surpass endogenous antioxidant defense and cause cell damage.

The underlying mechanisms of all these factors are only incompletely understood. During ischemia, NADPH oxidases interact with HIF [49-51,53-55] and may play a role in oxygen sensing [47, 48, 57]. However, the involvement of individual NOX isoforms and whether inhibition or rather enhancing NADPH oxidase activity during this phase is the appropriate therapeutic approach is unclear.

During reperfusion, NADPH oxidase inhibition could be a new therapeutic option in acute events, such as stroke or MI, if it is possible to intervene exactly during this period. Patients diagnosed with ischemic stroke or MI could be treated with NADPH oxidase inhibitors even before measures to establish reperfusion are taken. Also, in patients in whom reperfusion has already occurred endogenously, treatment with an NADPH oxidase inhibitor could be initiated in the early phase of reperfusion. For example, in brain IRI, inhibition of NOX4 post-reperfusion is beneficial in mice after an ischemic stroke [62]. NOX4 has been found in mitochondria [40]. As mitochondrial ROS likely have detrimental roles in the acute damaging phase after $\mathrm{I} / \mathrm{R}$ of the heart [124], reducing mitochondrial ROS generation by NOX4 inhibition is an attractive strategy. NOX2 may also be a good target in this condition, since an inflammatory reaction and disturbed BBB promotes the influx of neutrophils into the ischemic brain area [85]. However, data regarding NOX2 are conflicting [88]. In heart IRI, even more NOX isoforms may play a role [22]. Importantly, NOX5, the only NOX isoform, which is activated by calcium, is a potential target to reduce oxidative stress in VSMC [39, 140] as well as in EC [38] and possibly also directly in the heart. Unfortunately, due to the lack of NOX5 in rats and mice, no in vivo data on the role of NOX5 in animal models of MI are available.

During the third post-reperfusion phase, ROS appear to be needed for angiogenesis [15]. However, at the same time, they can be detrimental in promoting hypertrophy or dilatation. Here, not only the amount of ROS and the place where they are produced, but also the underlying causes of remodeling seem crucial, as is shown by divergent results in different pressure overload models [141, 142]. In chronic ischemic diseases, such as peripheral artery disease (PAD), the inhibition of NADPH oxidases could lead to an even more impaired blood flow [114] via interfering with angiogenesis. Here, NADPH oxidase-stimulated angiogenesis could lead to a better preserved vascularization and oxygen delivery within the peripheral tissues [67]. Thus, the activation of specific NOX isoforms at specific locations may here be a therapeutic option for PAD patients. Since NOX1, NOX2, and NOX4 are expressed in both VSMCs and ECs [22], they all seem to be possible targets in chronic ischemic disease states.

\section{NADPH oxidase inhibitors}

As is clear from the discussion in the previous chapter, complete inhibition of NADPH oxidase activities may not be a good strategy. Rather, it is important to delineate the precise roles of individual NOX isoforms, and it may turn out that one isoform should be inhibited, while another should be left untouched or even activated. Isoformspecific NOX inhibitors developed as therapeutic drugs could be used at specific time points during IRI.

Due to the high degree of structural similarity among the NOX enzymes [22], the development of isoform-selective NADPH oxidase inhibitors seems difficult. However, to avoid unforeseeable and potentially severe side effects of unselective NOX inhibition, this is highly desired. Currently, there is only one NOX isoform-specific inhibitor published, which is the NOX2 inhibitory peptide gp91ds-tat [143]. However, peptides are not orally bioavailable and probably do not show suitable pharmacokinetic parameters for clinical applications. Thus, small-molecule inhibitors are better suited. Nevertheless, published small-molecule NADPH oxidase inhibitors with some degree of selectivity for one NOX isoform, such as ML171 [144] and M090 [145] (NOX1 selectivity), do not seem to have satisfying pharmacokinetic properties. Other inhibitors, both isoformselective and isoform-unselective, have not yet been thoroughly investigated for off-target effects and toxicity, for example, fulvene-5, VAS2870, M090, and to some degree, ML171 [82, 144-146]. VAS2870 has been shown to reduce ROS production in vitro [147] and to diminish brain damage after stroke in vivo [62]. However, initially, VAS2870 seemed to be specific for NADPH oxidases [138], but recently, potential off-target effects of VAS2870 have been reported [148] with thiol alkylation as the likely mechanism of action of VAS2870-mediated NADPH oxidase inhibition. Clearly, the importance of this off-target alkylation or possible other off-target effects of VAS2870 need further analysis. The first inhibitor showing suitable toxicity and high oral bioavailability was the NOX1 and NOX4 inhibitor 
GKT136901 [149], which was further optimized to GKT137831. The latter compound is now in a phase I clinical study for the indication diabetic nephropathy.

In summary, (isoform)-specific NOX inhibitors or stimulators with a good pharmacodynamic and pharmacokinetic profile would be a significant step forward in the treatment of diseases, in which IRI plays a role.

\section{Summary and outlook}

Isoform-selective inhibition of NADPH oxidases seems to be a promising strategy to treat stroke and MI. Instead of scavenging ROS with antioxidants, selective blockade of ROS production at pathologically important sites may open new doors for therapies. Timing of selective NOX blockade may be of utmost importance because of the opposing effects in the different phases of IRI. In the postreperfusion phase, stimulation of NADPH oxidases might even be an option. The same may hold true for more chronic ischemic diseases, in which ROS likely mediate angiogenesis. Thus, it is clear that unraveling the precise sequence of events and differential roles of the NADPH oxidase-ROS axis is crucial for successful therapeutic clinical translation. Keeping in mind the double-edged sword that NADPH oxidases present, we must defeat the detrimental effects and possibly embrace the beneficial effects at the same time.

Acknowledgments The authors wish to acknowledge the national and international competitive grant support by the NHMRC, EU, and ERC (HHHWS).

Conflict of interest HHHWS is a cofounder of Vasopharm $\mathrm{GmbH}$, which has developed a NOX inhibitor, and also holds shares of Vasopharm GmbH.

\section{References}

1. Eltzschig HK, Collard CD (2004) Vascular ischaemia and reperfusion injury. Br Med Bull 70:71-86

2. Maxwell SR, Lip GY (1997) Reperfusion injury: a review of the pathophysiology, clinical manifestations and therapeutic options. Int J Cardiol 58:95-117

3. Vivekananthan DP, Penn MS, Sapp SK, Hsu A, Topol EJ (2003) Use of antioxidant vitamins for the prevention of cardiovascular disease: meta-analysis of randomised trials. Lancet 361:2017-2023

4. Bath PM, Gray LJ, Bath AJ, Buchan A, Miyata T, Green AR (2009) Effects of NXY-059 in experimental stroke: an individual animal meta-analysis. Br J Pharmacol 157:1157-1171

5. Andreadou I, Iliodromitis EK, Farmakis D, Kremastinos DT (2009) To prevent, protect and save the ischemic heart: antioxidants revisited. Expert Opin Ther Targets 13:945-956

6. Jaxa-Chamiec T, Bednarz B, Herbaczynska-Cedro K, Maciejewski P, Ceremuzynski L (2009) Effects of vitamins C and E on the outcome after acute myocardial infarction in diabetics: a retrospective, hypothesis-generating analysis from the MIVIT study. Cardiology 112:219-223

7. Griendling KK, Sorescu D, Ushio-Fukai M (2000) NAD(P)H oxidase: role in cardiovascular biology and disease. Circ Res $86: 494-501$

8. Gourdin MJ, Bree B, De Kock M (2009) The impact of ischaemia-reperfusion on the blood vessel. Eur J Anaesthesiol 26:537-547

9. Yellon DM, Hausenloy DJ (2007) Myocardial reperfusion injury. N Engl J Med 357:1121-1135

10. Forstermann U (2008) Oxidative stress in vascular disease: causes, defense mechanisms and potential therapies. Nat Clin Pract Cardiovasc Med 5:338-349

11. Elahi MM, Kong YX, Matata BM (2009) Oxidative stress as a mediator of cardiovascular disease. Oxid Med Cell Longev 2:259-269

12. Griendling KK, FitzGerald GA (2003) Oxidative stress and cardiovascular injury: part I: basic mechanisms and in vivo monitoring of ROS. Circulation 108:1912-1916

13. Braunwald E, Kloner RA (1985) Myocardial reperfusion: a double-edged sword? J Clin Invest 76:1713-1719

14. Maulik N (2002) Redox regulation of vascular angiogenesis. Antioxid Redox Signal 4:783-784

15. Maulik N, Das DK (2002) Redox signaling in vascular angiogenesis. Free Radic Biol Med 33:1047-1060

16. Berry CE, Hare JM (2004) Xanthine oxidoreductase and cardiovascular disease: molecular mechanisms and pathophysiological implications. J Physiol 555:589-606

17. Di Lisa F, Bernardi P (2006) Mitochondria and ischemiareperfusion injury of the heart: fixing a hole. Cardiovasc Res 70:191-199

18. Di Lisa F, Canton M, Menabo R, Kaludercic N, Bernardi P (2007) Mitochondria and cardioprotection. Heart Fail Rev 12:249-260

19. Gao L, Laude K, Cai H (2008) Mitochondrial pathophysiology, reactive oxygen species, and cardiovascular diseases. Vet Clin North Am Small Anim Pract 38:137-155, vi

20. Harrison R (2002) Structure and function of xanthine oxidoreductase: where are we now? Free Radic Biol Med 33:774-797

21. Meneshian A, Bulkley GB (2002) The physiology of endothelial xanthine oxidase: from urate catabolism to reperfusion injury to inflammatory signal transduction. Microcirculation 9:161-175

22. Cave AC, Brewer AC, Narayanapanicker A, Ray R, Grieve DJ, Walker S, Shah AM (2006) NADPH oxidases in cardiovascular health and disease. Antioxid Redox Signal 8:691-728

23. Lambeth JD (2004) NOX enzymes and the biology of reactive oxygen. Nat Rev Immunol 4:181-189

24. Lassegue B, Griendling KK (2010) NADPH oxidases: functions and pathologies in the vasculature. Arterioscler Thromb Vasc Biol 30:653-661

25. Sirker A, Zhang M, Shah AM (2011) NADPH oxidases in cardiovascular disease: insights from in vivo models and clinical studies. Basic Res Cardiol 106:735-747

26. Rivera J, Sobey CG, Walduck AK, Drummond GR (2010) Nox isoforms in vascular pathophysiology: insights from transgenic and knockout mouse models. Redox Rep 15:50-63

27. Guzik TJ, Harrison DG (2006) Vascular NADPH oxidases as drug targets for novel antioxidant strategies. Drug Discov Today 11:524-533

28. Bedard K, Krause KH (2007) The NOX family of ROSgenerating NADPH oxidases: physiology and pathophysiology. Physiol Rev 87:245-313

29. Hamilton CA, Miller WH, Al-Benna S, Brosnan MJ, Drummond RD, McBride MW, Dominiczak AF (2004) Strategies to reduce oxidative stress in cardiovascular disease. Clin Sci (Lond) 106:219-234 
30. Williams HC, Griendling KK (2007) NADPH oxidase inhibitors: new antihypertensive agents? J Cardiovasc Pharmacol 50:9-16

31. Geiszt M (2006) NADPH oxidases: new kids on the block. Cardiovasc Res 71:289-299

32. Lassegue B, Clempus RE (2003) Vascular NAD(P)H oxidases: specific features, expression, and regulation. Am J Physiol Regul Integr Comp Physiol 285:R277-R297

33. Gorlach A, Brandes RP, Nguyen K, Amidi M, Dehghani F, Busse R (2000) A gp91phox containing NADPH oxidase selectively expressed in endothelial cells is a major source of oxygen radical generation in the arterial wall. Circ Res 87:26-32

34. Jones SA, O'Donnell VB, Wood JD, Broughton JP, Hughes EJ, Jones OT (1996) Expression of phagocyte NADPH oxidase components in human endothelial cells. Am J Physiol 271: H1626-H1634

35. Wingler K, Wunsch S, Kreutz R, Rothermund L, Paul M, Schmidt HH (2001) Upregulation of the vascular NAD(P)Hoxidase isoforms Nox1 and Nox4 by the renin-angiotensin system in vitro and in vivo. Free Radic Biol Med 31:1456-1464

36. Miller AA, Drummond GR, Schmidt HH, Sobey CG (2005) NADPH oxidase activity and function are profoundly greater in cerebral versus systemic arteries. Circ Res 97:1055-1062

37. Miller AA, Drummond GR, Mast AE, Schmidt HH, Sobey CG (2007) Effect of gender on NADPH-oxidase activity, expression, and function in the cerebral circulation: role of estrogen. Stroke; J Cereb Circ 38:2142-2149

38. BelAiba RS, Djordjevic T, Petry A, Diemer K, Bonello S, Banfi B, Hess J, Pogrebniak A, Bickel C, Gorlach A (2007) NOX5 variants are functionally active in endothelial cells. Free Radic Biol Med 42:446-459

39. Jay DB, Papaharalambus CA, Seidel-Rogol B, Dikalova AE, Lassegue B, Griendling KK (2008) Nox5 mediates PDGFinduced proliferation in human aortic smooth muscle cells. Free Radic Biol Med 45:329-335

40. Block K, Gorin Y, Abboud HE (2009) Subcellular localization of Nox4 and regulation in diabetes. Proc Natl Acad Sci U S A 106:14385-14390

41. Hilenski LL, Clempus RE, Quinn MT, Lambeth JD, Griendling KK (2004) Distinct subcellular localizations of Nox1 and Nox4 in vascular smooth muscle cells. Arterioscler Thromb Vasc Biol 24:677-683

42. Lobysheva I, Rath G, Sekkali B, Bouzin C, Feron O, Gallez B, Dessy C, Balligand JL (2011) Moderate caveolin-1 downregulation prevents NADPH oxidase-dependent endothelial nitric oxide synthase uncoupling by angiotensin II in endothelial cells. Arterioscler Thromb Vasc Biol 31:2098-2105

43. Ambasta RK, Kumar P, Griendling KK, Schmidt HH, Busse R, Brandes RP (2004) Direct interaction of the novel Nox proteins with p22phox is required for the formation of a functionally active NADPH oxidase. J Biol Chem 279:45935-45941

44. Opitz N, Drummond GR, Selemidis S, Meurer S, Schmidt HH (2007) The 'A's and 'O's of NADPH oxidase regulation: a commentary on "Subcellular localization and function of alternatively spliced Noxo1 isoforms". Free Radic Biol Med 42:175-179

45. Brandes RP, Miller FJ, Beer S, Haendeler J, Hoffmann J, Ha T, Holland SM, Gorlach A, Busse R (2002) The vascular NADPH oxidase subunit $\mathrm{p} 47 \mathrm{phox}$ is involved in redox-mediated gene expression. Free Radic Biol Med 32:1116-1122

46. Djordjevic T, Pogrebniak A, BelAiba RS, Bonello S, Wotzlaw C, Acker H, Hess J, Gorlach A (2005) The expression of the NADPH oxidase subunit $\mathrm{p} 22$ phox is regulated by a redox-sensitive pathway in endothelial cells. Free Radic Biol Med 38:616-630

47. He L, Chen J, Dinger B, Sanders K, Sundar K, Hoidal J, Fidone S (2002) Characteristics of carotid body chemosensitivity in NADPH oxidase-deficient mice. Am J Physiol Cell Physiol 282:C27-C33
48. Jones RD, Hancock JT, Morice AH (2000) NADPH oxidase: a universal oxygen sensor? Free Radic Biol Med 29:416-424

49. Block K, Gorin Y, Hoover P, Williams P, Chelmicki T, Clark RA, Yoneda T, Abboud HE (2007) NAD(P)H oxidases regulate HIF2alpha protein expression. J Biol Chem 282:8019-8026

50. Diebold I, Flugel D, Becht S, Belaiba RS, Bonello S, Hess J, Kietzmann T, Gorlach A (2010) The hypoxia-inducible factor2alpha is stabilized by oxidative stress involving NOX4. Antioxid Redox Signal 13:425-436

51. Diebold I, Petry A, Hess J, Gorlach A (2010) The NADPH oxidase subunit NOX4 is a new target gene of the hypoxiainducible factor-1. Mol Biol Cell 21:2087-2096

52. Gorlach A, Diebold I, Schini-Kerth VB, Berchner-Pfannschmidt U, Roth U, Brandes RP, Kietzmann T, Busse R (2001) Thrombin activates the hypoxia-inducible factor-1 signaling pathway in vascular smooth muscle cells: role of the p22(phox)-containing NADPH oxidase. Circ Res 89:47-54

53. Goyal P, Weissmann N, Grimminger F, Hegel C, Bader L, Rose F, Fink L, Ghofrani HA, Schermuly RT, Schmidt HH et al (2004) Upregulation of $\mathrm{NAD}(\mathrm{P}) \mathrm{H}$ oxidase 1 in hypoxia activates hypoxia-inducible factor 1 via increase in reactive oxygen species. Free Radic Biol Med 36:1279-1288

54. Yuan G, Khan SA, Luo W, Nanduri J, Semenza GL, Prabhakar NR (2011) Hypoxia-inducible factor 1 mediates increased expression of NADPH oxidase-2 in response to intermittent hypoxia. J Cell Physiol 226:2925-2933

55. Yuan G, Nanduri J, Khan S, Semenza GL, Prabhakar NR (2008) Induction of HIF-1alpha expression by intermittent hypoxia: involvement of NADPH oxidase, $\mathrm{Ca}^{2+}$ signaling, prolyl hydroxylases, and mTOR. J Cell Physiol 217:674-685

56. Archer SL, Reeve HL, Michelakis E, Puttagunta L, Waite R, Nelson DP, Dinauer MC, Weir EK (1999) $\mathrm{O}_{2}$ sensing is preserved in mice lacking the gp91 phox subunit of NADPH oxidase. Proc Natl Acad Sci U S A 96:7944-7949

57. He L, Dinger B, Sanders K, Hoidal J, Obeso A, Stensaas L, Fidone S, Gonzalez C (2005) Effect of p47phox gene deletion on ROS production and oxygen sensing in mouse carotid body chemoreceptor cells. Am J Physiol Lung Cell Mol Physiol 289: L916-L924

58. Roy A, Rozanov C, Mokashi A, Daudu P, Al-mehdi AB, Shams $\mathrm{H}$, Lahiri S (2000) Mice lacking in gp91 phox subunit of NAD (P)H oxidase showed glomus cell $[\mathrm{Ca}(2+)](\mathrm{i})$ and respiratory responses to hypoxia. Brain Res 872:188-193

59. Mittal M, Roth M, Konig P, Hofmann S, Dony E, Goyal P, Selbitz AC, Schermuly RT, Ghofrani HA, Kwapiszewska G et al (2007) Hypoxia-dependent regulation of nonphagocytic NADPH oxidase subunit NOX4 in the pulmonary vasculature. Circ Res 101:258-267

60. Rupin A, Paysant J, Sansilvestri-Morel P, Lembrez N, Lacoste JM, Cordi A, Verbeuren TJ (2004) Role of NADPH oxidasemediated superoxide production in the regulation of E-selectin expression by endothelial cells subjected to anoxia/reoxygenation. Cardiovasc Res 63:323-330

61. Hong H, Zeng JS, Kreulen DL, Kaufman DI, Chen AF (2006) Atorvastatin protects against cerebral infarction via inhibition of NADPH oxidase-derived superoxide in ischemic stroke. Am J Physiol Heart Circ Physiol 291:H2210-H2215

62. Kleinschnitz C, Grund H, Wingler K, Armitage ME, Jones E, Mittal M, Barit D, Schwarz T, Geis C, Kraft P, Barthel K, Schuhmann MK, Herrmann AM, Meuth SG, Stoll G, Meurer S, Schrewe A, Becker L, Gailus-Durner V, Fuchs H, Klopstock T, de Angelis MH, Jandeleit-Dahm K, Shah AM, Weissmann N, Schmidt HH (2010) Post-stroke inhibition of induced NADPH oxidase type 4 prevents oxidative stress and neurodegeneration. PLoS Biol 8(9). pii: e1000479

63. Vallet P, Charnay Y, Steger K, Ogier-Denis E, Kovari E, Herrmann F, Michel JP, Szanto I (2005) Neuronal expression of the NADPH 
oxidase NOX4, and its regulation in mouse experimental brain ischemia. Neuroscience 132:233-238

64. Doerries C, Grote K, Hilfiker-Kleiner D, Luchtefeld M, Schaefer A, Holland SM, Sorrentino S, Manes C, Schieffer B, Drexler H et al (2007) Critical role of the NAD(P)H oxidase subunit p47phox for left ventricular remodeling/dysfunction and survival after myocardial infarction. Circ Res 100:894-903

65. Looi YH, Grieve DJ, Siva A, Walker SJ, Anilkumar N, Cave AC, Marber M, Monaghan MJ, Shah AM (2008) Involvement of Nox2 NADPH oxidase in adverse cardiac remodeling after myocardial infarction. Hypertension 51:319-325

66. Zhao W, Zhao D, Yan R, Sun Y (2009) Cardiac oxidative stress and remodeling following infarction: role of NADPH oxidase. Cardiovasc Pathol 18:156-166

67. Craige SM, Chen K, Pei Y, Li C, Huang X, Chen C, Shibata R, Sato K, Walsh K, Keaney JF Jr (2011) NADPH oxidase 4 promotes endothelial angiogenesis through endothelial nitric oxide synthase activation. Circulation 124:731-740

68. Kietzmann T, Gorlach A (2005) Reactive oxygen species in the control of hypoxia-inducible factor-mediated gene expression. Semin Cell Dev Biol 16:474-486

69. Semenza GL (2007) Hypoxia-inducible factor 1 (HIF-1) pathway. Sci STKE 2007(407):cm8

70. Dery MA, Michaud MD, Richard DE (2005) Hypoxia-inducible factor 1: regulation by hypoxic and non-hypoxic activators. Int $\mathrm{J}$ Biochem Cell Biol 37:535-540

71. Bonello S, Zahringer C, BelAiba RS, Djordjevic T, Hess J, Michiels C, Kietzmann T, Gorlach A (2007) Reactive oxygen species activate the HIF-1alpha promoter via a functional NFkappaB site. Arterioscler Thromb Vasc Biol 27:755-761

72. Diebold I, Djordjevic T, Hess J, Gorlach A (2008) Rac-1 promotes pulmonary artery smooth muscle cell proliferation by upregulation of plasminogen activator inhibitor-1: role of NFkappaB-dependent hypoxia-inducible factor-1alpha transcription. Thromb Haemost 100:1021-1028

73. Diebold IPA, Sabrane K, Djordjevic T, Hess J, Görlach (2012) The HIF1 target gene NOX2 promotes angiogenesis through urotensin-II. J Cell Sci 125:956-964

74. Gorlach A, Berchner-Pfannschmidt U, Wotzlaw C, Cool RH, Fandrey J, Acker H, Jungermann K, Kietzmann T (2003) Reactive oxygen species modulate HIF-1 mediated PAI-1 expression: involvement of the GTPase Rac1. Thromb Haemost 89:926-935

75. Hirota K, Semenza GL (2001) Rac1 activity is required for the activation of hypoxia-inducible factor 1. J Biol Chem 276:2116621172

76. Chen H, Song YS, Chan PH (2009) Inhibition of NADPH oxidase is neuroprotective after ischemia-reperfusion. J Cereb Blood Flow Metab 29:1262-1272

77. Chen H, Kim GS, Okami N, Narasimhan P, Chan PH (2011) NADPH oxidase is involved in post-ischemic brain inflammation. Neurobiol Dis 42:341-348

78. Yang Z, Sharma AK, Marshall M, Kron IL, Laubach VE (2009) NADPH oxidase in bone marrow-derived cells mediates pulmonary ischemia-reperfusion injury. Am J Respir Cell Mol Biol 40:375-381

79. Heumuller S, Wind S, Barbosa-Sicard E, Schmidt HH, Busse R, Schroder K, Brandes RP (2008) Apocynin is not an inhibitor of vascular NADPH oxidases but an antioxidant. Hypertension 51:211-217

80. Borchi E, Parri M, Papucci L, Becatti M, Nassi N, Nassi P, Nediani C (2009) Role of NADPH oxidase in H9c2 cardiac muscle cells exposed to simulated ischaemia-reperfusion. J Cell Mol Med 13:2724-2735

81. Meischl C, Krijnen PA, Sipkens JA, Cillessen SA, Munoz IG, Okroj M, Ramska M, Muller A, Visser CA, Musters RJ et al (2006) Ischemia induces nuclear NOX2 expression in cardiomyocytes and subsequently activates apoptosis. Apoptosis 11:913-921

82. Wind S, Beuerlein K, Eucker T, Muller H, Scheurer P, Armitage ME, Ho H, Schmidt HH, Wingler K (2010) Comparative pharmacology of chemically distinct NADPH oxidase inhibitors. Br J Pharmacol 161:885-898

83. Jackman KA, Miller AA, Drummond GR, Sobey CG (2009) Importance of NOX1 for angiotensin II-induced cerebrovascular superoxide production and cortical infarct volume following ischemic stroke. Brain Res 1286:215-220

84. Kahles T, Kohnen A, Heumueller S, Rappert A, Bechmann I, Liebner S, Wittko IM, Neumann-Haefelin T, Steinmetz H, Schroeder K et al (2010) NADPH oxidase Nox1 contributes to ischemic injury in experimental stroke in mice. Neurobiol Dis 40:185-192

85. Brait VH, Jackman KA, Walduck AK, Selemidis S, Diep H, Mast AE, Guida E, Broughton BR, Drummond GR, Sobey CG (2010) Mechanisms contributing to cerebral infarct size after stroke: gender, reperfusion, T lymphocytes, and Nox2-derived superoxide. J Cereb Blood Flow Metab 30:1306-1317

86. Kahles T, Luedike P, Endres M, Galla HJ, Steinmetz H, Busse R, Neumann-Haefelin T, Brandes RP (2007) NADPH oxidase plays a central role in blood-brain barrier damage in experimental stroke. Stroke 38:3000-3006

87. Walder CE, Green SP, Darbonne WC, Mathias J, Rae J, Dinauer MC, Curnutte JT, Thomas GR (1997) Ischemic stroke injury is reduced in mice lacking a functional NADPH oxidase. Stroke 28:2252-2258

88. Radermacher KA, Wingler K, Kleikers PW, Altenhofer SA, Hermans JR, Kleinschnitz C, Schmidt HH (2012) The 1027th target candidate in stroke: will NADPH oxidase hold up? Exp Transl Stroke Med 4:11

89. Duilio C, Ambrosio G, Kuppusamy P, DiPaula A, Becker LC, Zweier JL (2001) Neutrophils are primary source of $\mathrm{O}_{2}$ radicals during reperfusion after prolonged myocardial ischemia. Am J Physiol Heart Circ Physiol 280:H2649-H2657

90. Weissmann N, Sydykov A, Kalwa H, Storch U, Fuchs B, Mederos y Schnitzler M, Brandes RP, Grimminger F, Meissner M, Freichel M et al (2012) Activation of TRPC6 channels is essential for lung ischaemia-reperfusion induced oedema in mice. Nat Commun 3:649

91. Clempus RE, Sorescu D, Dikalova AE, Pounkova L, Jo P, Sorescu GP, Schmidt HH, Lassegue B, Griendling KK (2007) Nox4 is required for maintenance of the differentiated vascular smooth muscle cell phenotype. Arterioscler Thromb Vasc Biol 27:42-48

92. Cucoranu I, Clempus R, Dikalova A, Phelan PJ, Ariyan S, Dikalov S, Sorescu D (2005) NAD(P)H oxidase 4 mediates transforming growth factor-beta1-induced differentiation of cardiac fibroblasts into myofibroblasts. Circ Res 97:900-907

93. Deliri H, McNamara CA (2007) Nox 4 regulation of vascular smooth muscle cell differentiation marker gene expression. Arterioscler Thromb Vasc Biol 27:12-14

94. Frey RS, Ushio-Fukai M, Malik AB (2009) NADPH oxidasedependent signaling in endothelial cells: role in physiology and pathophysiology. Antioxid Redox Signal 11:791-810

95. Li JM, Shah AM (2004) Endothelial cell superoxide generation: regulation and relevance for cardiovascular pathophysiology. Am J Physiol Regul Integr Comp Physiol 287:R1014-R1030

96. Ushio-Fukai M (2006) Redox signaling in angiogenesis: role of NADPH oxidase. Cardiovasc Res 71:226-235

97. Ushio-Fukai M, Alexander RW (2004) Reactive oxygen species as mediators of angiogenesis signaling: role of $\mathrm{NAD}(\mathrm{P}) \mathrm{H}$ oxidase. Mol Cell Biochem 264:85-97

98. Ushio-Fukai M, Tang Y, Fukai T, Dikalov SI, Ma Y, Fujimoto M, Quinn MT, Pagano PJ, Johnson C, Alexander RW (2002) Novel role of gp91(phox)-containing $\mathrm{NAD}(\mathrm{P}) \mathrm{H}$ oxidase in vascular 
endothelial growth factor-induced signaling and angiogenesis. Circ Res 91:1160-1167

99. Abid MR, Spokes KC, Shih SC, Aird WC (2007) NADPH oxidase activity selectively modulates vascular endothelial growth factor signaling pathways. J Biol Chem 282:35373-35385

100. Urao N, Inomata H, Razvi M, Kim HW, Wary K, McKinney R, Fukai T, Ushio-Fukai M (2008) Role of nox2-based NADPH oxidase in bone marrow and progenitor cell function involved in neovascularization induced by hindlimb ischemia. Circ Res 103:212-220

101. Tojo T, Ushio-Fukai M, Yamaoka-Tojo M, Ikeda S, Patrushev N, Alexander RW (2005) Role of gp91phox (Nox2)-containing $\mathrm{NAD}(\mathrm{P}) \mathrm{H}$ oxidase in angiogenesis in response to hindlimb ischemia. Circulation 111:2347-2355

102. Distasi MR, Case J, Ziegler MA, Dinauer MC, Yoder MC, Haneline LS, Dalsing MC, Miller SJ, Labarrere CA, Murphy MP et al (2009) Suppressed hindlimb perfusion in Rac2-/- and Nox2-/- mice does not result from impaired collateral growth. Am J Physiol Heart Circ Physiol 296:H877-H886

103. Haddad P, Dussault S, Groleau J, Turgeon J, Michaud SE, Menard C, Perez G, Maingrette F, Rivard A (2009) Nox2containing NADPH oxidase deficiency confers protection from hindlimb ischemia in conditions of increased oxidative stress. Arterioscler Thromb Vasc Biol 29:1522-1528

104. Ebrahimian TG, Heymes C, You D, Blanc-Brude O, Mees B, Waeckel L, Duriez M, Vilar J, Brandes RP, Levy BI et al (2006) NADPH oxidase-derived overproduction of reactive oxygen species impairs postischemic neovascularization in mice with type 1 diabetes. Am J Pathol 169:719-728

105. Frantz S, Brandes RP, Hu K, Rammelt K, Wolf J, Scheuermann H, Ertl G, Bauersachs J (2006) Left ventricular remodeling after myocardial infarction in mice with targeted deletion of the NADPH oxidase subunit gp91PHOX. Basic Res Cardiol 101:127-132

106. van den Borne SW, van de Schans VA, Strzelecka AE, VervoortPeters HT, Lijnen PM, Cleutjens JP, Smits JF, Daemen MJ, Janssen BJ, Blankesteijn WM (2009) Mouse strain determines the outcome of wound healing after myocardial infarction. Cardiovasc Res 84:273-282

107. Hoffmeyer MR, Jones SP, Ross CR, Sharp B, Grisham MB, Laroux FS, Stalker TJ, Scalia R, Lefer DJ (2000) Myocardial ischemia/reperfusion injury in NADPH oxidase-deficient mice. Circ Res 87:812-817

108. Arbiser JL, Petros J, Klafter R, Govindajaran B, McLaughlin ER, Brown LF, Cohen C, Moses M, Kilroy S, Arnold RS et al (2002) Reactive oxygen generated by Nox1 triggers the angiogenic switch. Proc Natl Acad Sci U S A 99:715-720

109. Dikalova A, Clempus R, Lassegue B, Cheng G, McCoy J, Dikalov S, San Martin A, Lyle A, Weber DS, Weiss D et al (2005) Nox1 overexpression potentiates angiotensin II-induced hypertension and vascular smooth muscle hypertrophy in transgenic mice. Circulation 112:2668-2676

110. Arnold RS, Shi J, Murad E, Whalen AM, Sun CQ, Polavarapu R, Parthasarathy S, Petros JA, Lambeth JD (2001) Hydrogen peroxide mediates the cell growth and transformation caused by the mitogenic oxidase Nox1. Proc Natl Acad Sci U S A 98:5550-5555

111. Suh YA, Arnold RS, Lassegue B, Shi J, Xu X, Sorescu D, Chung AB, Griendling KK, Lambeth JD (1999) Cell transformation by the superoxide-generating oxidase Mox1. Nature 401:79-82

112. Datla SR, Peshavariya H, Dusting GJ, Mahadev K, Goldstein BJ, Jiang F (2007) Important role of Nox4 type NADPH oxidase in angiogenic responses in human microvascular endothelial cells in vitro. Arterioscler Thromb Vasc Biol 27:2319-2324

113. Schroder K, Wandzioch K, Helmcke I, Brandes RP (2009) Nox4 acts as a switch between differentiation and proliferation in preadipocytes. Arterioscler Thromb Vasc Biol 29:239-245
114. Schroder K, Zhang M, Benkhoff S, Mieth A, Pliquett R, Kosowski J, Kruse C, Luedike P, Michaelis UR, Weissmann N et al (2012) Nox4 is a protective reactive oxygen species generating vascular NADPH oxidase. Circ Res 110:1217-1225

115. Maejima Y, Kuroda J, Matsushima S, Ago T, Sadoshima J (2011) Regulation of myocardial growth and death by NADPH oxidase. J Mol Cell Cardiol 50:408-416

116. Djordjevic T, BelAiba RS, Bonello S, Pfeilschifter J, Hess J, Gorlach A (2005) Human urotensin II is a novel activator of NADPH oxidase in human pulmonary artery smooth muscle cells. Arterioscler Thromb Vasc Biol 25:519-525

117. Sturrock A, Cahill B, Norman K, Huecksteadt TP, Hill K, Sanders K, Karwande SV, Stringham JC, Bull DA, Gleich M et al (2006) Transforming growth factor-betal induces Nox4 NAD(P)H oxidase and reactive oxygen species-dependent proliferation in human pulmonary artery smooth muscle cells. Am J Physiol Lung Cell Mol Physiol 290:L661-L673

118. Ago T, Kuroda J, Pain J, Fu C, Li H, Sadoshima J (2010) Upregulation of Nox4 by hypertrophic stimuli promotes apoptosis and mitochondrial dysfunction in cardiac myocytes. Circ Res 106:1253-1264

119. Boueiz A, Damarla M, Hassoun PM (2008) Xanthine oxidoreductase in respiratory and cardiovascular disorders. Am J Physiol Lung Cell Mol Physiol 294:L830-L840

120. Armitage ME, Wingler K, Schmidt HH, La M (2009) Translating the oxidative stress hypothesis into the clinic: NOX versus NOS. J Mol Med 87:1071-1076

121. Otani H (2009) The role of nitric oxide in myocardial repair and remodeling. Antioxid Redox Signal 11:1913-1928

122. Cai H, Harrison DG (2000) Endothelial dysfunction in cardiovascular diseases: the role of oxidant stress. Circ Res 87:840-844

123. Otani H (2008) Ischemic preconditioning: from molecular mechanisms to therapeutic opportunities. Antioxid Redox Signal 10:207-247

124. Chen Q, Camara AK, Stowe DF, Hoppel CL, Lesnefsky EJ (2007) Modulation of electron transport protects cardiac mitochondria and decreases myocardial injury during ischemia and reperfusion. Am J Physiol Cell Physiol 292:C137-C147

125. Choi K, Kim J, Kim GW, Choi C (2009) Oxidative stress-induced necrotic cell death via mitochondria-dependent burst of reactive oxygen species. Curr Neurovasc Res 6:213-222

126. Loor G, Kondapalli J, Iwase H, Chandel NS, Waypa GB, Guzy RD, Vanden Hoek TL, Schumacker PT (2011) Mitochondrial oxidant stress triggers cell death in simulated ischemia-reperfusion. Biochim Biophys Acta 1813:1382-1394

127. Perrelli MG, Pagliaro P, Penna C (2011) Ischemia/reperfusion injury and cardioprotective mechanisms: role of mitochondria and reactive oxygen species. World J Cardiol 3:186-200

128. Dikalov S (2011) Cross talk between mitochondria and NADPH oxidases. Free Radic Biol Med 51:1289-1301

129. Gustafsson AB, Gottlieb RA (2008) Heart mitochondria: gates of life and death. Cardiovasc Res 77:334-343

130. Zorov DB, Juhaszova M, Sollott SJ (2006) Mitochondrial ROSinduced ROS release: an update and review. Biochim Biophys Acta 1757:509-517

131. Kimura S, Zhang GX, Nishiyama A, Shokoji T, Yao L, Fan YY, Rahman M, Suzuki T, Maeta H, Abe Y (2005) Role of NAD(P)H oxidase- and mitochondria-derived reactive oxygen species in cardioprotection of ischemic reperfusion injury by angiotensin II. Hypertension 45:860-866

132. Matsuzaki S, Szweda PA, Szweda LI, Humphries KM (2009) Regulated production of free radicals by the mitochondrial electron transport chain: cardiac ischemic preconditioning. Adv Drug Deliv Rev 61:1324-1331

133. Novelli GP, Adembri C, Gandini E, Orlandini SZ, Papucci L, Formigli L, Manneschi LI, Quattrone A, Pratesi C, Capaccioli S 
(1997) Vitamin E protects human skeletal muscle from damage during surgical ischemia-reperfusion. Am J Surg 173:206-209

134. Flaherty JT, Pitt B, Gruber JW, Heuser RR, Rothbaum DA, Burwell LR, George BS, Kereiakes DJ, Deitchman D, Gustafson $\mathrm{N}$ et al (1994) Recombinant human superoxide dismutase (hSOD) fails to improve recovery of ventricular function in patients undergoing coronary angioplasty for acute myocardial infarction. Circulation 89:1982-1991

135. Rapola JM, Virtamo J, Ripatti S, Huttunen JK, Albanes D, Taylor PR, Heinonen OP (1997) Randomised trial of alpha-tocopherol and beta-carotene supplements on incidence of major coronary events in men with previous myocardial infarction. Lancet 349:1715-1720

136. Bailey DM, Raman S, McEneny J, Young IS, Parham KL, Hullin DA, Davies B, McKeeman G, McCord JM, Lewis MH (2006) Vitamin C prophylaxis promotes oxidative lipid damage during surgical ischemia-reperfusion. Free Radic Biol Med 40:591-600

137. Bjelakovic G, Nikolova D, Gluud LL, Simonetti RG, Gluud C (2007) Mortality in randomized trials of antioxidant supplements for primary and secondary prevention: systematic review and meta-analysis. JAMA 297:842-857

138. Wingler K, Hermans J, Schiffers P, Moens A, Paul M, Schmidt H (2011) NOX 1, 2, 4, 5: counting out oxidative stress. Br J Pharmacol 164:866-883

139. Griendling KK, FitzGerald GA (2003) Oxidative stress and cardiovascular injury: part II: animal and human studies. Circulation 108:2034-2040

140. Guzik TJ, Chen W, Gongora MC, Guzik B, Lob HE, Mangalat D, Hoch N, Dikalov S, Rudzinski P, Kapelak B et al (2008) Calcium-dependent NOX5 nicotinamide adenine dinucleotide phosphate oxidase contributes to vascular oxidative stress in human coronary artery disease. J Am Coll Cardiol 52:1803-1809

141. Kuroda J, Ago T, Matsushima S, Zhai P, Schneider MD, Sadoshima J (2010) NADPH oxidase 4 (Nox4) is a major source of oxidative stress in the failing heart. Proc Natl Acad Sci U S A 107:15565-15570

142. Zhang M, Brewer AC, Schroder K, Santos CX, Grieve DJ, Wang M, Anilkumar N, Yu B, Dong X, Walker SJ et al (2010) NADPH oxidase-4 mediates protection against chronic loadinduced stress in mouse hearts by enhancing angiogenesis. Proc Natl Acad Sci U S A 107:18121-18126
143. Rey FE, Cifuentes ME, Kiarash A, Quinn MT, Pagano PJ (2001) Novel competitive inhibitor of $\mathrm{NAD}(\mathrm{P}) \mathrm{H}$ oxidase assembly attenuates vascular $\mathrm{O}(2)(-)$ and systolic blood pressure in mice. Circ Res 89:408-414

144. Gianni D, Taulet N, Zhang H, DerMardirossian C, Kister J, Martinez L, Roush WR, Brown SJ, Bokoch GM, Rosen H (2010) A novel and specific NADPH oxidase-1 (Nox1) smallmolecule inhibitor blocks the formation of functional invadopodia in human colon cancer cells. ACS Chem Biol 5:981-993

145. Brown SJ, Gianni D, Bokoch G, Mercer BA, Hodder P, Rosen HR (2010) Probe report for NOX1 inhibitors. Probe Reports from the Molecular Libraries Program, National Center for Biotechnology Information, Bethesda

146. Bhandarkar SS (2009) Fulvene-5 potently inhibits NADPH oxidase 4 and blocks the growth of endothelial tumors in mice. J Clin Investig 119:2359-2365

147. Stielow C, Catar RA, Muller G, Wingler K, Scheurer P, Schmidt HH, Morawietz H (2006) Novel Nox inhibitor of oxLDL-induced reactive oxygen species formation in human endothelial cells. Biochem Biophys Res Commun 344:200-205

148. Sun QA, Hess DT, Wang B, Miyagi M, Stamler JS (2012) Offtarget thiol alkylation by the NADPH oxidase inhibitor 3-benzyl7-(2-benzoxazolyl)thio-1,2,3-triazolo[4,5-d]pyrimidine (VAS2870). Free Radic Biol Med 52:1897-1902

149. Laleu B, Gaggini F, Orchard M, Fioraso-Cartier L, Cagnon L, Houngninou-Molango S, Gradia A, Duboux G, Merlot C, Heitz F et al (2010) First in class, potent, and orally bioavailable NADPH oxidase isoform 4 (Nox4) inhibitors for the treatment of idiopathic pulmonary fibrosis. J Med Chem 53:7715-7730

150. Kunz A, Anrather J, Zhou P, Orio M, Iadecola C (2007) Cyclooxygenase-2 does not contribute to postischemic production of reactive oxygen species. J Cereb Blood Flow Metab: Off J Int Soc Cereb Blood Flow and Metab 27:545-551

151. Li J, Stouffs M, Serrander L, Banfi B, Bettiol E, Charnay Y, Steger K, Krause KH, Jaconi ME (2006) The NADPH oxidase NOX4 drives cardiac differentiation: role in regulating cardiac transcription factors and MAP kinase activation. Mol Biol Cell 17:3978-3988

152. Lyle AN, Deshpande NN, Taniyama Y, Seidel-Rogol B, Pounkova L, Du P, Papaharalambus C, Lassegue B, Griendling KK (2009) Poldip2, a novel regulator of Nox4 and cytoskeletal integrity in vascular smooth muscle cells. Circ Res 105:249-259 